\title{
Threat of falling high status and corporate bribery: Evidence from the revealed accounting records of two South Korean presidents
}

\author{
Yujin Jeong $^{1}$ | Jordan I. Siegel ${ }^{2}$
}

${ }^{1}$ Department of International Business, Kogod School of Business, American University, Washington, District of Columbia

${ }^{2}$ Strategy Area, Ross School of Business, University of Michigan, Ann Arbor, Michigan

\section{Correspondence}

Yujin Jeong, Kogod School of Business,

American University, 4400 Massachusetts Avenue NW, Washington, DC 20016.

Email: yjeong@american.edu

Funding information

Academy of Korean Studies, Grant/Award number: AKS-2015-R33
Research Summary: Social status and its dynamics may be an important predictor of which firms will engage in large-scale bribery. Prior theory is incomplete, however, and prior studies have lacked comprehensive and reliable data on firm-level bribery decisions. We offer a new theoretical prediction and a novel data set on high-level corruption in South Korea, where the accounting records of two presidents in the 1987-1992 era were exposed to after-the-fact legal and public scrutiny. We find that, controlling for a range of alternative explanations, the threat of falling high status-that is, the combination of longstanding high social status with current-period mediocre economic performance relative to that of industry peersis a statistically and economically meaningful predictor of increases in the amount of large-scale corporate bribery.

Managerial Summary: What leads companies to engage in large-scale bribery of senior politicians? Our concept of "threat of falling high status" refers to a circumstance where companies that have historically enjoyed high status through their owner families' elite marriage networks experience mediocre economic performance relative to their peers. We show that this threat of falling high status is a notable determinant of large-scale corporate bribery of senior politicians, using court data on corporate bribery of two South Korean presidents during 1987-1992. The implication of our study is twofold. Companies can strengthen internal control systems to avoid any largescale illegal activities at a higher level. Law enforcement agencies can also implement targeted monitoring programs to preempt illegal activities among companies facing the threat of falling high status. 


\section{KEYWORDS}

bribery, corruption, nonmarket strategy, political

network, status

\section{1 | INTRODUCTION}

One of the principal ways in which firms can seek competitive advantage is through nonmarket strategy (Baron, 2013), defined as seeking to influence governmental actors to attain favorable treatment and regulation. Despite the fact that much of the nonmarket strategy literature has focused on lobbying and political contributions, and despite the magnitude of corruption in the global economy, estimated at \$1 trillion per year (Kaufmann, 2006, p. 83), few studies have examined high-level corruption where companies pay bribes to senior politicians. Pioneering work in the theory of corruption has been mostly based on political economy (Rose-Ackerman, 1975, 1978, 1999; Shleifer \& Vishny, 1993). Evidence on the firm-level determinants of bribery has largely drawn on surveys and proxy indicators (e.g., Chavis, 2013; Clarke \& Xu, 2004; Martin, Cullen, Johnson, \& Parboteeah, 2007; Svensson, 2003); two notable exceptions are Jeong and Weiner (2012), using data from the United Nations' Oil-for-Food Program (UN OFFP) made available as a result of public investigation, and Cheung, Rau, and Stouraitis (2012), utilizing media-reported data on cases of corporate bribery.

Building on this pioneering work, we study what leads firms to engage in large-scale bribery of high-level politicians. Studying this question from a nonmarket-strategy perspective matters: highlevel politicians are known to make decisions that critically impact the competitive landscape. Inspired by the fields of sociology, behavioral economics, and criminology, we examine the effect of a threat of falling high status on the amount of bribes that firms paid. We term "threat of falling high status" the concept in which a firm has longstanding high social status (defined here as being at the center of the elite marriage network between controlling owner-families) but is threatened with an impending fall in status due to current-period mediocre economic performance relative to that of industry peers. We test our theoretical concept using extensive documentation of high-level bribery in South Korea, where two former presidents, Chun Doo-Hwan (Chun) and Roh Tae-Woo (Roh), received bribes from business groups ${ }^{1}$ during their terms of office and were subsequently prosecuted. Their internal accounting books were unexpectedly revealed to the public in the course of the country's democratization.

Scholarly efforts to explain why some firms engage in large-scale bribery of high-level government officials while others do not have run into three main challenges. First, the illegal nature of corruption resulted in few past studies of firm-level determinants of bribery based on reliable data. To our knowledge, prior to the current study, only the data on the UN OFFP used in Jeong and Weiner (2012) specify the amounts of bribes to high-level government officials paid by individual firms, in that case to the Iraqi government, as a result of public investigation. ${ }^{2}$

\footnotetext{
${ }^{1}$ Business groups in South Korea are also called chaebol, a family-controlled and diversified group of businesses and similar to those business groups that exist through most of the world outside of the U.S. and the UK.

${ }^{2}$ Several other studies, though not focused on firm-level determinants, are noteworthy for utilizing unique data to measure the socialwelfare costs of bribery (e.g., Fisman \& Miguel, 2007; Fisman \& Wei, 2009; McMillan \& Zoido, 2004; Olken \& Barron, 2009;
} 
Second, prior studies have relied on companies' self-reporting, which is apt to be unreliable. ${ }^{3}$ Firms may have reason to dissemble when it comes to their own illicit conduct. In contrast, the accounting records we rely on came to light through court rulings, national legislative hearings, and media scrutiny. South Korea's 1996 "Trial of the Century," which exposed the full accounting books of Chun and Roh, resulted in criminal convictions for them and for the chairmen of several leading business groups, including Samsung and Daewoo. These data enable us to overcome the critical issue of data reliability and comprehensiveness in studies of corruption.

Third, while theories based on political economy have made important contributions to the understanding of corruption (Rose-Ackerman, 1978, 1999), further progress is likely to benefit from an interdisciplinary approach drawing on sociology, behavioral economics, and criminology. Research on firm-level determinants of bribery has focused on bargaining-power-based determinants from economic theory (Svensson, 2003) and on companies' financial and ownership characteristics (Chavis, 2013; Clarke \& Xu, 2004; Jeong \& Weiner, 2012). This literature has not yet looked at such other plausible determinants as social comparison effects (Ball, Eckel, Grossman, \& Zame, 2001). Companies' perceptions of how they are positioned relative to peer companies, in the market and in society (that is, their relative status), could have a large impact on their bribery behavior.

This study aims to extend our understanding of corporate bribery via a combination of theory development, focused on the relationship between the threat of falling high status and bribery, and empirical analysis of a novel data set. The combination of (a) bribery data from court rulings and investigative reports and (b) our hand-collected data on South Korean business groups' marriagenetwork standing enables us to examine whether a socioeconomic condition, threat of falling high status, influences firms' bribery decisions and behavior. Padgett and McLean (2006) and Ingram and Lifschitz (2006) demonstrate that patterns of exchange relations are manifestations of social logics, and that these social logics persist from one context to another. In emerging economies, marriage networks and the dense circles of trust that they generate are typically the foundation of elite business networks (Bunkanwanicha, Fan, \& Wiwattanakantang, 2013; Kogut, 2012). Lacking wellfunctioning governance institutions, most emerging economies must rely heavily on social trust to get business done. Thus, to foreshadow our use of a modern-day example from the large emerging economy of South Korea, historical deference in the elite marriage-matching market (whereby, like in many countries across the globe, only certain families for decades got to marry their children into other elite families) leads to current-period deference between family-run business groups in the economic marketplace (Greve, Han, \& Shipilov, 2016; Kang, 2002, p. 114).

Even when a family-run business group enjoys the benefits of high status-including favorable access to resources, privileged treatment by the government, and deference from peers in terms of market-entry decisions - those benefits can be quickly lost if the business group starts to lag behind its peers in economic performance (Amsden, 1989, 2001; Greve et al., 2016). Status was gained

Sequeira \& Djankov, 2014). For example, McMillan and Zoido (2004) analyzed the Peruvian spy chief's payment of bribes to judges and television broadcasters. Olken and Barron (2009) used direct observation of bribe payments via experiment to examine how bribes are negotiated in the setting of Indonesia trucking. Sequeira and Djankov (2014) also used direct observation of bribe payments via experiment to examine the impact of corruption on firm-level trade costs in African ports. Because our data provide comprehensive coverage of high-level bribery by firms to the government, it differs from prior work focused on bribery by Montesinos in the 1990s-era Peruvian government to judges, congressman, and television station owners (McMillan \& Zoido, 2004), as well as other pioneering work by Fisman and coauthors on measuring and capturing the economic importance of corruption (e.g., Fisman, 2001; Fisman \& Miguel, 2007; Fisman \& Wei, 2009).

${ }^{3}$ The focus on self-reporting led Svensson (2003: 225), in what is the pioneering empirical study of which firms engage in bribery, to say that he could not use even his well-crafted survey questions about similar firms in the same line of business to study levels in actual bribes made by focal companies. Jeong and Weiner (2012) also report no statistically meaningful bivariate relationship between survey-based perceived corruption and actual corruption measured by firm-level bribery amounts to the Iraqi government during the UN OFFP. 
through historically-demonstrated superior economic performance, and status can be promptly lost by current-period economic performance that is running behind one's peer groups. As we know from the prior literature on the economic development of South Korea (Amsden, 1989, 2001), business groups originally achieved high status by means of historically superior economic performance, a phenomenon similar to the concept of historically-determined status legacy (Malter, 2014; Washington \& Zajac, 2005). A number of business groups that enjoyed high status in the 1960s subsequently failed to deliver superior economic performance and dropped out of the high-status elite (Amsden, 1989). A key mechanism was that mediocre performance rapidly led the next generation of their families to no longer be attractive partners in the elite marriage market, which then made their business groups receive less deference and fewer resources in the economic marketplace, which in turn led to further rapid erosion of their economic position. In South Korea, which is a dynamically competitive economy, this process in fact occurred promptly for some business groups that were in the social elite in the 1960s.

As a result, those under threat of falling high status - that is, those historically endowed with high status in the marriage market but facing current-time mediocre performance relative to peersmay engage more in illicit bribery designed to raise their performance in the economic market. Business groups under threat of falling high status will be motivated, as seen in Askin and Bothner (2016), to attempt a radical change in their actions. For reasons of motivation, resource availability, and inability to compete through other market means, we predict that firms under threat of falling high status will pay larger bribes to high-level government officials than all other firms, all else equal.

In the next section, we develop the theoretical concept of the threat of falling high status and how it relates to corporate bribery. Next, we discuss our empirical context and strategy. We then present results and conclude by discussing the implications of our findings.

\section{2 | THEORY AND HYPOTHESIS}

\section{1 | Status and bribery}

Status, as succinctly defined by Ball et al. (2001, p. 161), is "a ranking in a hierarchy that is socially recognized and typically carries with it the expectation of entitlement to certain resources." High status is thus a high position in a ranked pecking order of individuals or firms; it is often of first-order importance as an individual- or firm-level objective. For firms, status is not purely financial but also socially embedded and historically persistent. Adam Smith, the father of neoclassical economics, was a pioneering theorist on the role of social status (which he called "place") in economic decision-making. An oft-forgotten insight of Adam Smith's is that status is a direct source of utility and provides important benefits of deference from others (1759/1976, p. 52). Status has in fact been shown in numerous experimental and empirical studies to have key market benefits. As shown in a laboratory experimental market by Ball et al. (2001), those with higher status (even when that status is randomly assigned) are able to sell a generic good at higher prices and thus to capture a greater share of a surplus than their lower-status counterparts. Not only are lower-status actors willing to pay more to purchase goods from higher-status actors; higher status actors are also able to secure more favorable outcomes in the marriage matching market that codifies high status (even controlling for their wealth) (Almenberg \& Dreber, 2009).

One universal phenomenon of achieving and cementing social status is through marriage. Marriage of children between business families has long been seen in the field of business history as a 
key form of cementing status of the owner-managers of those businesses (Barker, 2017; Grassby, 2001; Padgett \& Ansell, 1993). We know not just from the historical work of Padgett and Ansell (1993), but also of more recent work in emerging economies (as but one example, see Bunkanwanicha et al., 2013) that one of the key objectives for elite business families is to secure high social status through marriage of their children to other elite business families. While the U.S. and the UK are today outliers relative to the rest of the world for their relatively dispersed corporate ownership, even the business history of the U.S. reflects the historic role of marriage between the families controlling business groups to cement social status (such as the marriage union between Andrew Carnegie's family based in steel with other elite industrial families of its time).

The importance of looking at the interaction between social ties, including elite marriage ties, and their influence on corporate strategic behavior is well pointed out by the message from Kogut (2012, p. 49) that if we are interested in the linkage between institutions and strategy, we should closely examine the fact that "institutions are rooted in norms and social rules." As Kogut also points out in the same piece, the study of marriage and related networks has gone from being a "staple industry of sociology to a subject of interest in computer science, applied physics, economics, and other natural and social sciences" (Kogut, 2012, p. 3). As Kogut goes on to explicate, "Part of this interest reflects the interest in understanding how micro-behaviors (e.g., social rules of who marries whom, who buys what, etc.) govern the topology of the network" (2012, p. 3). We take this fundamental insight one step further by looking at the effect of the threat of falling high status in the elite marriage network on actual corporate nonmarket behavior (in this case, corporate bribery of senior government officials).

We will discuss below how three distinct literatures, in behavioral economics, criminology, and sociology, provide theory and/or empirical findings that help make sense of the radical actions that firms will take when faced with the threat of the loss of high status. Foundational support from these three fields will help build our concept of the threat of falling high status and explicate its effect on motivating certain firms to pay large-scale bribes to high-level government officials.

\subsection{1 | Behavioral economics}

The literature of behavioral economics shows that it is maximally painful to fall from an initial position of high status. Kahneman and Tversky's seminal work (Kahneman \& Tversky, 1979) shows that perceived pain from pending losses is most severe when starting at an initial high point (e.g., see the examples in Kahneman, 2013. pp. 275-277, 302-304). Building on Kahneman and Tversky's work, Kern and Chugh (2009) show in a series of lab experiments that people are more likely to engage in unethical behavior when operating in a loss-frame context (in which an unethical choice increases the probability of avoiding a potential loss) than in a gain-frame context (in which an unethical choice increases the probability of potential gain). Participants in their study were more likely to choose unethical behavior to avoid a 75\% probability of losing a business sale than to secure a $25 \%$ probability of gaining a potential sale. Grolleau, Kocher, and Sutan (2016) similarly show that people are so threatened by a potential loss of income that their level of cheating at a simple task shoots upward when they are suddenly faced with an immediate threat of income loss.

Balasubramanian, Bennett, and Pierce (2017) also provide survey- and simulation-based evidence that the internal costs of dishonesty are convex: that is, dishonesty increases as rewards increase, but decreases at the highest reward levels. In our theoretical context, this pattern predicts smaller gains from bribery for those whose high status is most secure. In other words, those with very secure high status may experience higher internal costs of dishonesty (e.g., greater loss in reputation and brand from being revealed as dishonest) and have little further to gain from bribery since their (industry- 
adjusted) performance is already far better than peers'. By contrast, those temporarily insecure about their high status tend to perceive high short-term rewards from resorting to bribery as a pathway back to high-ranking performance and secure high status. They also tend to view bribery as temporary and transient, which may well lower the internal costs of dishonesty (Balasubramanian et al., 2017).

\subsection{2 | Criminology}

The criminology literature also offers foundational support for the threat of falling high status and corporate bribery. Applying the logic of Kahneman and Tversky in his field study of white-collar criminals, Wheeler speculates (Wheeler, 1992, p. 114) that "fear of falling" is a leading cause of whitecollar crime. Similarly, Weisburd, Wheeler, Waring, and Bode (1991) portray an individual who, having attained wealth and status through honest hard work, faces an impending drop in income and justifies short-term crime as a temporary means of recapturing the original position (Weisburd et al., 1991, p. 189). Wheeler (1992, p. 119) described his portrayal of the typical white-collar criminal as speculative, but also contemplated whether a similar logic would apply to firms and their leadership groups. Another important insight from the criminology literature is that fear of status loss is about those with high status who are experiencing a short-term financial setback. It is noteworthy that the sudden adversity that the focal individuals or firms face (in terms of mediocre financial performance) and that can lead to status loss is on a different dimension (financial performance) from the dimension (elite marriage ties) in which their status was originally formed. Also, the choice to engage in shortterm criminality is based on a belief in the possibility of a realistic recovery and consolidation of high status. This implies, in our research context, that it is not those high-status firms with the most severe financial problems that can lead to bankruptcy or failure that will engage in large-scale bribery or other similarly significant misconduct (Weisburd et al., 1991; Wheeler, 1992).

\subsection{3 | Sociology and related organizational theory}

Early empirical research in sociology was inconclusive about the impact of status on unethical behavior, perhaps because it focused solely on high status and not on the threat of losing high status. Those prior studies offered opposing arguments (which tend to cancel each other out) on whether high status might lead directly to nonconformity with social norms (e.g., Dittes \& Kelley, 1956). On the one hand, high-status firms may be more likely to engage in large-scale bribery because they are confident that their high status affords them license to engage in deviant behavior (Becker, 1963; Dittes \& Kelley, 1956), because they have more resources to spend on bribery, or because they think they can more easily hide their bribery behavior (through slick relationship management or sneakier accounting). On the other hand, such firms might reject bribery because they can generate higher returns by investing in $R \& D$ and marketing; or because they have attained such dominant market power that they will not incrementally gain from bribery; or because detection would endanger their brands at higher cost and imperil their ultimate profitability; or because public expectations of exemplary conduct on their part would result in unusually harsh punishment if misconduct were discovered (Giordano, 1983). Given the opposing mechanisms described here, it is not surprising that the literature produced muddled and contradictory results. This suggests the need for the more fully specified logic that better explains who engages in large-scale corporate bribery.

In support of our thesis that the threat posed by a mismatch between firms' high status and current-period financial underperformance leads firms to engage in large-scale bribery, consider Rider and Tan's (2015) recent demonstration of what happens when high-status U.S. law firms lose employees to lower-status competitors. Those competitors are typically more profitable; thus, highstatus firms begin to lose the benefits of their status, including attracting and retaining talent in the 
labor market, if they suddenly become less profitable than lower-status firms. Given that such firms lack the market means to compete in terms of current-period profitability, one can conjecture that radical action, such as bribery, is among their few remaining options for securing needed resources to boost profitability and re-secure their high status.

Further inspiration for our focus on the mismatch between firms' high status and current-period mediocre economic performance can also be found in strain theory in sociology (Merton, 1968). Inspired in part by the work of Cyert and March (1963), Greve (2003) showed that companies are more likely to engage in misconduct if they are underperforming peers or underperforming relative to their own past success. Strain theory thus suggests that organizations experiencing threats to their competitive position (Vaughan, 1999) may be more likely to engage in misconduct. ${ }^{4}$

We will eventually differ, however, from some latter-day strain theorists, including Mishina, Dykes, Block, and Pollock (2010), who found that firms performing well above their peers ultimately engaged in misconduct because of a combination of hubris and outsized performance expectations. Also, what Greve calls "aspiration levels" (2003, p. 3) are only one piece of the theoretical picture we aim to present. Firms aspire to membership in the high-status group, and anything that potentially mires them in limbo about their ongoing membership in the high-status group (and thus a fall into the next territory of middle status) will motivate them to consider whether short-term illegal conduct can offer a quick boost back into secure high-status territory. Our theory thus differs from that of Mishina et al. (2010)—which evokes the lyrics of "High Flying, Adored" from the musical Evita - that outsized expectations and hubris promote fraudulent conduct. Though we agree that firms constantly compare themselves to peers (Greve, 2003), we think that the more fully specified logic presented here explains more of the observed variation in corporate bribery.

\section{2 | The concept of the threat of falling high status}

Jointly, the literatures of behavioral economics, criminology, and sociology provide foundational insights for our concept of the threat of falling high status. The concept describes high status firms' fear of falling over into the next territory (hypothetically, middle status where the members of that group can enjoy only some of the benefits that high status group can fully enjoy) in the wake of the threat arising from a mismatch between high status and current-time mediocre economic performance relative to peers. This concept also suggests that it is not the direct effect of high status or of temporary financial underperformance, but the interaction effect of the two, that leads firms threatened by a fall in high status to pay larger bribes than all other firms, ceteris paribus. The interaction between the two also suggests that the dimension on which status was originally gained need not be the one on which its loss is threatened. In our research context, strong financial performance historically led to high status cemented via elite marriage, and then it is poor financial underperformance that starts to threaten high status. Past studies also indicate that fear of status loss leads to concrete expenditure on unethical action (Weisburd et al., 1991; Wheeler, 1992) only in the presence of a combination of available/liquid resources, talent/capabilities, and realistic prospects of securing a positive, long-term return to high status by engaging in unethical actions. In other words, those experiencing the most severe financial problems, and thus lagging far behind their peers, will typically lack the resources necessary to bribe on a large scale.

\footnotetext{
${ }^{4}$ Martin et al. (2007) show, for example, through firms' self-reporting in World Bank surveys that if they perceive a greater number of competitors that are viable threats to their competitive advantage, then they are more likely to report that firms in their country environment often engage in bribery.
} 
From the fields of strategy and organizational theory, there are three logical responses to the threat of falling high status. Firms can invest more in market-oriented capabilities, which we seek to control for, particularly R\&D, exporting, advertising, and training of employees. Their current-time mediocre performance, however, can prevent them from using legitimate economic means to produce the ongoing profit flows necessary to maintain and support their high status in a timely manner. As a result, they may look to bribery as a quick boost to secure the government-provided resources and treatment that can enable them to compete on market means over the longer term. Firms can also invest in relational ties, which we also seek to control for, such as personal ties to government actors. The last strategic option for firms is to choose direct bribes to politicians. It is worth noting that the U.S. is a unique country case in that it offers the legalized option of lobbying and of post-Citizens United direct corporate engagement in political campaigns; this formalized and legalized option is rare elsewhere. In many other countries, a direct bribe payment to politicians is among their few remaining options for a quick boost back into secure high-status territory.

While controlling for alternative choices and explanations, our focus here is primarily on the threat of falling high status as a determinant of large-scale corporate bribery, and on whether this unexplored socio-economic predictor can explain variability in large-scale bribery of high-level government officials. In summary, based on the combination of threat, resource availability to pay large-scale bribes, but inability to compete in the short run via market means, and belief that shortterm payment of large-scale bribes will deliver the politically-determined resources that will help them reclaim secure high-status standing, firms under threat of falling high status will engage in large-scale bribery of high-level government officials as a tool to address such a threat, ceteris paribus. This leads us to state the following central hypothesis of this study:

\begin{abstract}
Hypothesis The higher the socially endowed status that a business entity initially enjoys, the higher the amount of bribes it pays to government officials, following a threat of falling high status (socially-endowed high status interacted with mediocre economic performance relative to its peers).
\end{abstract}

\title{
3 | THE EMPIRICAL CONTEXT: SOUTH KOREA
}

We next turn to the empirical context in which we test our hypothesis. South Korea is an economically important test case. It is currently the world's 11th largest economy, with gross domestic product (GDP) of $\$ 1.38$ trillion according to the most recently available year 2015 data from the Work Bank's World Development Indicators. Even as early as the 1990 midpoint of our sample time period, South Korea was among the world's 15 largest economies (World Bank, 2017). South Korea is also representative of emerging economies: it is among the 65 countries that experienced the third wave of democratization (Huntington, 1991; Møller \& Skaaning, 2013, p. 99). Its level of corruption is comparable to many other countries' (e.g., it ranked 27 th out of the 41 countries that Transparency International surveyed for its first Corruption Perception Index in 1995 and 43rd out of 85 countries surveyed in 1998) $)^{5}$; and its corporate governance institutions rank similarly to those of numerous peer countries (La Porta, Lopez-de-Silanes, Shleifer, \& Vishny, 1997, 2000, 2002).

\footnotetext{
${ }^{5}$ As illustrated here, South Korea is one of a large number of countries where bribery is perceived to be moderate to severe, but also representative of a large number of countries where large-scale corporate bribery is condemned by the broader public. In Appendix S1, we provide our summary discussion on a series of South Korean public surveys on corporate bribery.
} 
Chun and Roh, both former army generals, led South Korea from 1980 to early 1993. Chun (1980-1988) seized power in a coup d'état following the death of the prior military dictator; Roh (1988-1993), Chun's chosen successor, was elected in 1987 when the two non-military leaders of the democracy movement could not unite behind one candidate and split the vote (e.g., see Seo, 2007). It has been widely documented, beginning as early as 1988, that during the Chun and Roh administrations some business groups influenced politicians and government bureaucrats with largescale bribes, and that these business groups received favored treatment in return for the bribes (e.g., see Kang, 2002; Kim, 1997; Park, 1988; Yoo, 1988). In the mid-1990s, during the country's democratic transition, Chun and Roh were prosecuted for corruption; their internal accounting books were unexpectedly opened up to the world by public investigation in 1995. Chun was ordered by the Seoul High Court to repay 220.5 billion won (\$256 million in 1996) received in bribes from business groups; Roh was ordered to repay 262.8 billion won ( $\$ 305$ million) received as bribes from business groups. Several prominent business group heads (including Samsung's Lee Kun-Hee and Daewoo's Kim Woo-Choong) were also found guilty of bribery (Suh, 1996).

The ramifications of paying bribes to Chun and Roh are apparent in several well-known cases. One conduit through which Chun collected bribes was the Ilhae Foundation, a quasi-research foundation that he established while in office. At a time when comparable business groups (e.g., Daewoo, Hyundai, Lotte, and Samsung) each contributed 3-4.5 billion won to Ilhae (Yoo, 1988, p. 389), Kukje Group, then the nation's seventh-largest business group, almost totally rejected the choice of paying bribes, ${ }^{6}$ contributing only 0.5 billion won to Ilhae, upon request. In 1985 the Chun administration announced Kukje's bankruptcy and dismembered the group. ${ }^{7}$ Numerous Kukje affiliates were then taken over by Hanil Synthetic Fiber (Hanil), Kukdong Construction, and Dongkuk Steel, all of which were much smaller than Kukje but had paid much larger bribes (e.g., see Kim, 1997; Yoo, 1988). Specifically, Hanil increased its 1986 contribution by 53\% over the preceding year; the same year, it acquired several Kukje affiliates. Its total 1983-1987 contributions ranked second among the top 30 business groups.

The final year of Chun's presidency (1987) saw more such activity-payment of more bribes than expected for purported benefits. Hanil's contributions reached nearly 7.3 billion won (an increase of 56\%) in 1987; that year Hanil acquired Jinhae Chemical, the largest producer of compound fertilizer. The contribution of Korean Air Line (KAL) grew suddenly by 66\% (to about 5.1 billion won) in 1987 vis-à-vis the year before. KAL subsequently acquired Korean Shipping Line, a company whose CEO testified at the 1989 national hearing that he had declined Chun's request for political funds. Most notably, Kumho Group, which operated express bus services, increased its contribution by more than $900 \%$ from 0.3 billion won in 1986 to nearly 2.8 billion won in 1987; Kumho's application to own and operate South Korea's second-largest private airline was accepted 1 day before Chun left office in 1988 (Yoo, 1988, p. 389).

Under the Roh administration, Samsung-facing a threat of falling high status-paid larger bribes than peers and received licenses and permits in industries like aerospace, automobiles, largescale construction, and in petrochemicals. ${ }^{8}$ Another example that supports our thesis is Doosan: during the Roh administration, when the company enjoyed fairly high social status and very high performance relative to peers, it paid few bribes. Interestingly, our court and financial data also show that Lotte, a group with high social status in the same time period, paid bribes whose amounts fluctuated a great deal: its payments were twice as high when its performance relative to peers was low,

\footnotetext{
${ }^{6}$ See Kim (1997, pp. 200-203), Kang (2002, pp. 102-104) and Rhee (2002, pp. 215-217).

${ }^{7}$ In 1993, the Constitutional Court of Korea ruled the government's dismembering Kukje Group as unconstitutional.

${ }^{8}$ Various media sources including Seoul Broadcasting News (12/11/2016).
} 
and typically low when its performance relative to peers was relatively high. We also see that Hanjin, whose social status was high under the Roh administration, paid a higher bribe when it faced the threat of falling high status, but not otherwise. Lastly, Hyundai paid high bribes for multiple years when it was facing the threat of falling high status and then stopped paying bribes when its performance relative to peers was markedly better at the end of the Roh administration.

\section{I EMPIRICAL STRATEGY}

\section{1 | Data}

Our bribery data come from two main sources: South Korea's court verdicts (The Seoul District Court, 1996; The Seoul High Court, 1996; The Supreme Court of Korea, 1997; hereafter the court data) and the special investigative report by The National Assembly of the Republic of Korea (1990, pp. 149-151, 264-284) produced as a result of the national hearings (1988) on high-level corruption scandals during the Chun administration. The Seoul District Court verdict (1996) indicates that companies paid a total bribe of 220.5 billion won (\$256 million) to Chun and 283.9 billion won (\$330 million) to Roh during their respective presidencies. The data show that, of the business entities large enough to be required to disclose audited financial statements in at least 2 years during the 1987-1992 time period, 40 business groups paid a bribe in at least 1 year during that sample time period. ${ }^{9}$ These 40 business groups constitute our sample, which provides us 237 group-year observations for our panel analysis (one of the 40 business groups has only 3 years of audited financial data; the other 39 groups have data for all 6 years of our sample time period).

Note that each of these 40 business groups had multiple affiliates, but was controlled by a single owner-shareholder family; bribes were paid not at the affiliate level but at the business-group level, through the group chairman's office, which is the dominion of the controlling owner-shareholder. As seen in the court records, these bribes were viewed and categorized as coming from the business group as a common entity controlled by the controlling owner-shareholder. Because each business group is controlled by a single person, who is head of an elite family, it also makes sense that the person would be focused in no small part on their individual and family aspirations, and that these individual and family aspirations would then get channeled into decision-making and behavior for the business group they control. This provides us a natural and logical connection from individual constructs of social status via elite marriage ties to firm decisions.

For our empirical analysis, we highlight two things. First, our sample of 40 business groups from the court data have towered over South Korea's economy during and after our sample time period. These 40 large business groups represent hundreds of large firms that collectively in turn represent a very high percentage of the total value-added in South Korea. This can be seen in terms of the 30 largest business groups' share of their total sales in South Korea's gross national product, which was $70.1 \%$ in 1988 (Cho, 1997, p. 81). It is also important to note that it is not the case that we are only including groups that gave bribes. The trial record showed that Chun and Roh focused on this specific set of 40 large business groups plus one other without sufficient accounting data and required solely that all such large business groups give at least a modest nominal bribe amount at

\footnotetext{
${ }^{9}$ We note that there were 13 other business entities that were originally reported in the court data to have paid at least modest-sized bribes to Chun and Roh, but 10 entities did not have affiliates meeting the minimal regulatory size standard for them to have to report publicly audited financial data during our sample time period. One business group (Kukje) was dismembered by Chun by the start of our sample time period, another business group (Hangyang) did not pay bribes in the 4 years during our sample time period in which it had publicly available financial data, and another (Asia Cement) did not meet the minimal regulatory size standard to have to report 2 or more years of publicly audited financial data during our sample time period. This leaves us with a sample of 40 business groups.
} 
least once. Kukje Group that refused to give anything was the outlier that was subsequently dismembered by Chun, as discussed earlier.

Second, our analysis focuses on the 1987-1992 time period because those are the years when fully audited firm-level financial data became publicly available in South Korea and because one of the main independent variables of interest is a firm-level predictor that relies on company financials. Although 1987, the last full year of the Chun administration, is the only year during the Chun administration for which we had full firm-level financial data, our sample time period 1987-1992 is representative of the overall era of Chun and Roh's presidencies given that Chun and Roh were political allies whose administrations are perceived as a single period of time. ${ }^{10}$

Also note that the Seoul High Court on an appeal let Chun relieve himself of legal penalty on a small subset of bribes involving five business groups in our sample. We choose deliberately not to drop those data because it is clear, according to numerous Korean sources that those bribes were in fact collected in the name of Chun by his closest aides and were used for political funds designed to benefit Chun. The only reason why Chun was able to relieve himself of legal penalty on those few observations is because the prosecutors could not prove that Chun himself had contacted the firms or received the funds in person. ${ }^{11}$ That said, Chun himself admitted in sworn testimony that he called for the collection of funds that were then collected by his closest aides and then deposited into a political fund designed to aid Chun's political group. Because some of the foundations that received funds were managed by Chun's spouse, we do not think it matters for this context whether Chun himself called up these firms or received the money in person. What matters is that the clique at the very top of the government received the payment and used it for the benefit of that clique.

We augment our bribery data from the Seoul District Court verdict by adding quasicontributions made by the 40 business groups to key quasi-foundations that Chun and his spouse established during Chun's presidency. They include, in addition to the Ilhae Foundation discussed earlier, the New Generation Heart Foundation and the New Generation Education Foundation established by Chun's spouse. These quasi-contribution data come from the special investigative report by The National Assembly of the Republic of Korea (1990). We cross-checked our bribery data with numerous media sources in South Korea. They include South Korea's major political periodicals, daily newspapers, books that analyzed the political era of Chun and Roh, and transcripts from South Korea's major news broadcasters (see Appendix S3 for specific sources we consulted).

Next, we match the bribe data with audited statutory financial statements from the National Information and Credit Evaluation (NICE) agency. NICE is the leading credit-rating agency in South Korea and is the major source of reliable financial statements of South Korean firms. To be included in the analysis, the statutory companies should meet our criteria of both being part of one of the 40 business groups and having financial data that are audited during this 1987-1992 time period. They include privately held affiliates that met the relatively modest asset requirements which made them subject to mandatory disclosure of financial statements.

Lastly, we construct our key covariate, "Threat of Falling High Status" (discussed below) using our hand-collected relational database. It shows the detailed marriage network among the controlling owners' families of South Korean business groups over time. This comprehensive marriage tie

\footnotetext{
${ }^{10}$ Appendix S2 provides photographic evidence that shows Chun and Roh when they were the military cadets of the 11th class (1951) of the Korean Military Academy and when they were later prosecuted and holding hands in their first public trial in 1996.

${ }^{11}$ We confirm this from the interview with Rhee Jong-Chan (the then chief of the central investigation department of the Supreme Prosecutor's Office of South Korea) conducted for this study in South Korea in 2015.
} 
1987

At the beginning of the sample time period
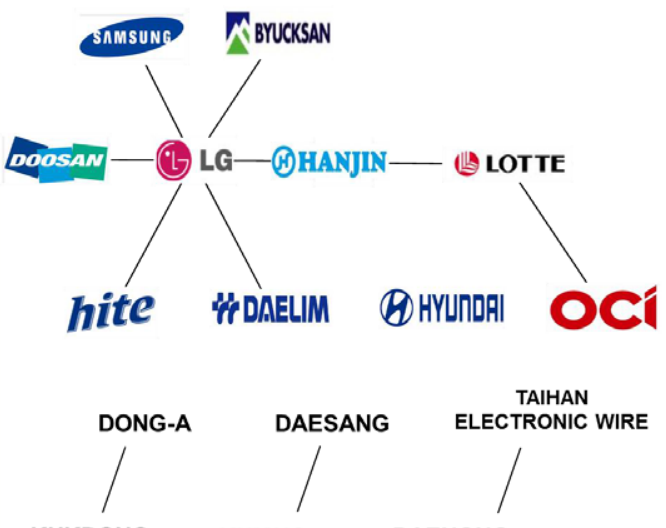

KUKDONG
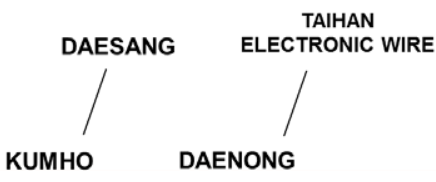

1992

At the end of the sample time period
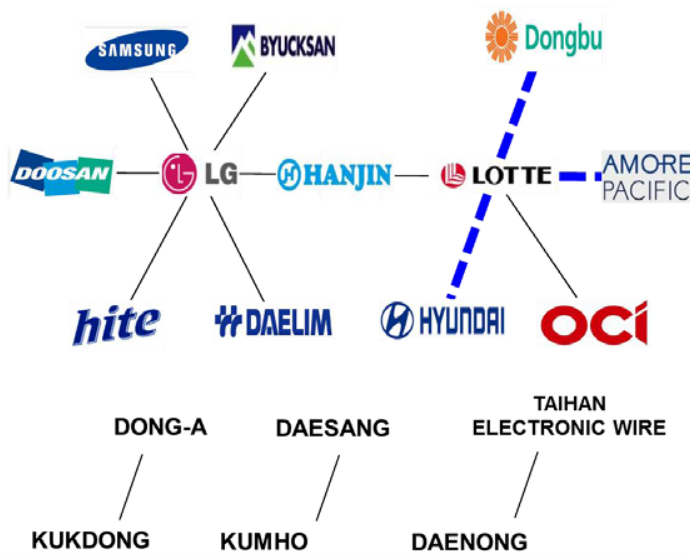

FIGURE 1 The marriage network among South Korean business groups at the beginning (1987) and the end (1992) of the sample time period

database was constructed and checked over time based on a number of different South Korea's online and offline sources for personal profiles. ${ }^{12}$ Figure 1 depicts those South Korean business groups with marriage ties to other South Korean business groups at the beginning and at the end of our 1987-1992 sample time period. A line between two business groups represents a direct marriage tie between them. Other business groups not in the figure are isolates without any marriage ties to any other South Korean business groups.

For our panel analysis below, we utilize 237 group-year observations because one of the 40 business groups in our sample has only 3 years of audited financial data whereas the other 39 groups have data for all 6 years of our sample time period.

\section{2 | Dependent variable}

Our dependent variable is "Yearly Bribe Paid by Business Group," which is the annual bribe amount (KRW billion) paid by each of the 40 business groups. As shown in Table 1, the annual group bribery amount ranges from zero to 14 billion won with an average of 1.45 billion won. During the sample time period (1987-1992), our exploratory data analysis also reveals that each business group paid 8.57 billion won on average over the 6 years ranging from 0.2 billion won to 35 billion won in total. Figure 2 describes each business group's total amount of bribes during the sample time period. Figure 3 depicts each business group's individual bribe amount by year. Each marker in Figure 3 is frequency weighted, thus the bigger the marker, the more the number of the same bribe amount by different business groups at each bribe level in that particular year.

\footnotetext{
${ }^{12}$ This database was constructed with the help of a team of research assistants in South Korea. Data on family structure and individual family members' resumes were collected and cross-checked with over 25 respected Korean data sources, including two personal profile databases (Donga and Joong-Ang) that collect life-long resumes on over 200,000 Korean citizens. While these two sources were highly impressive in their coverage, there were some missing data points. To maximize the comprehensive nature of the data set, we collected further data and cross-checked all observations mostly using the Korean Integrated News Database System (KINDS), the Korean version of Lexis-Nexis.
} 


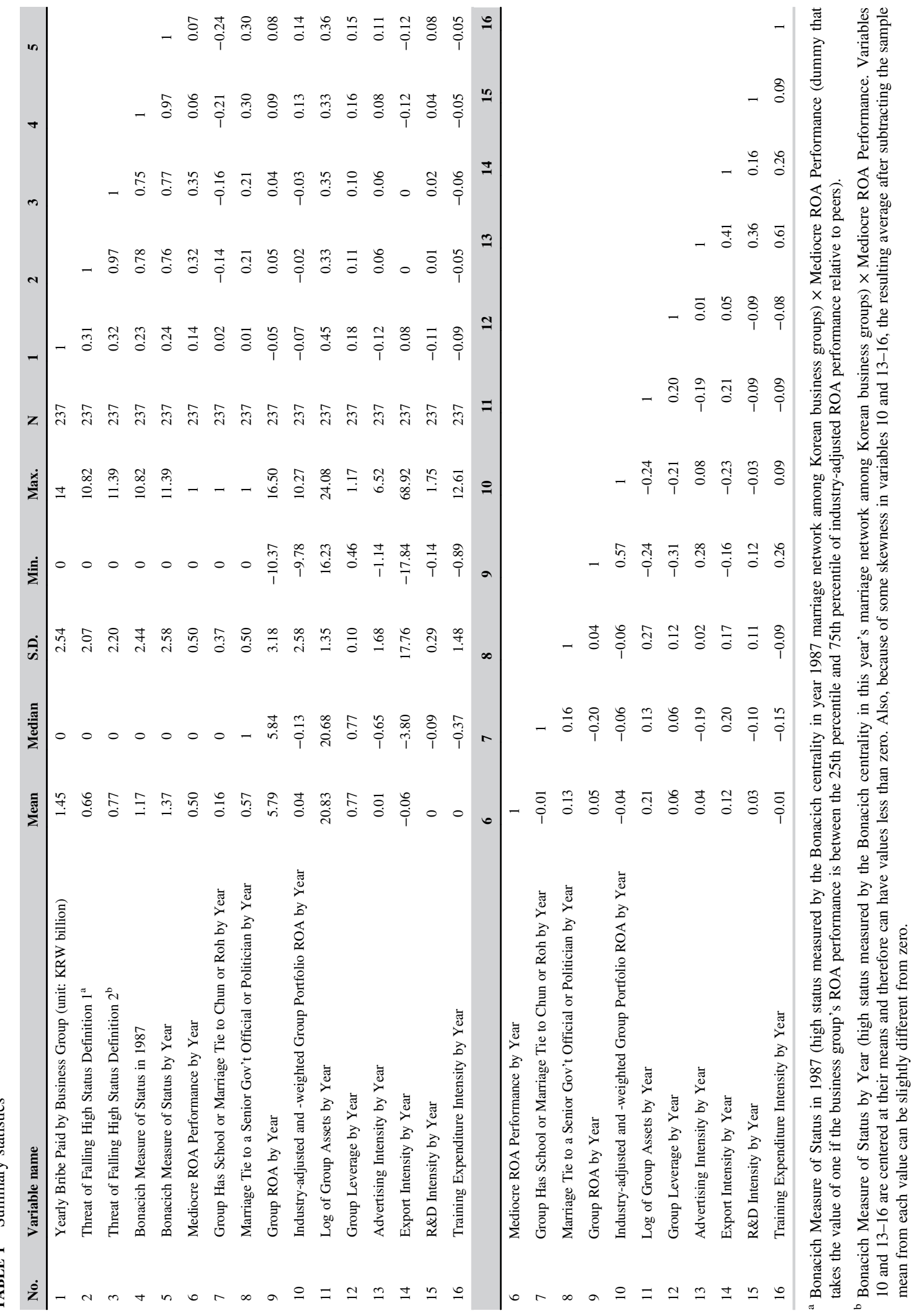




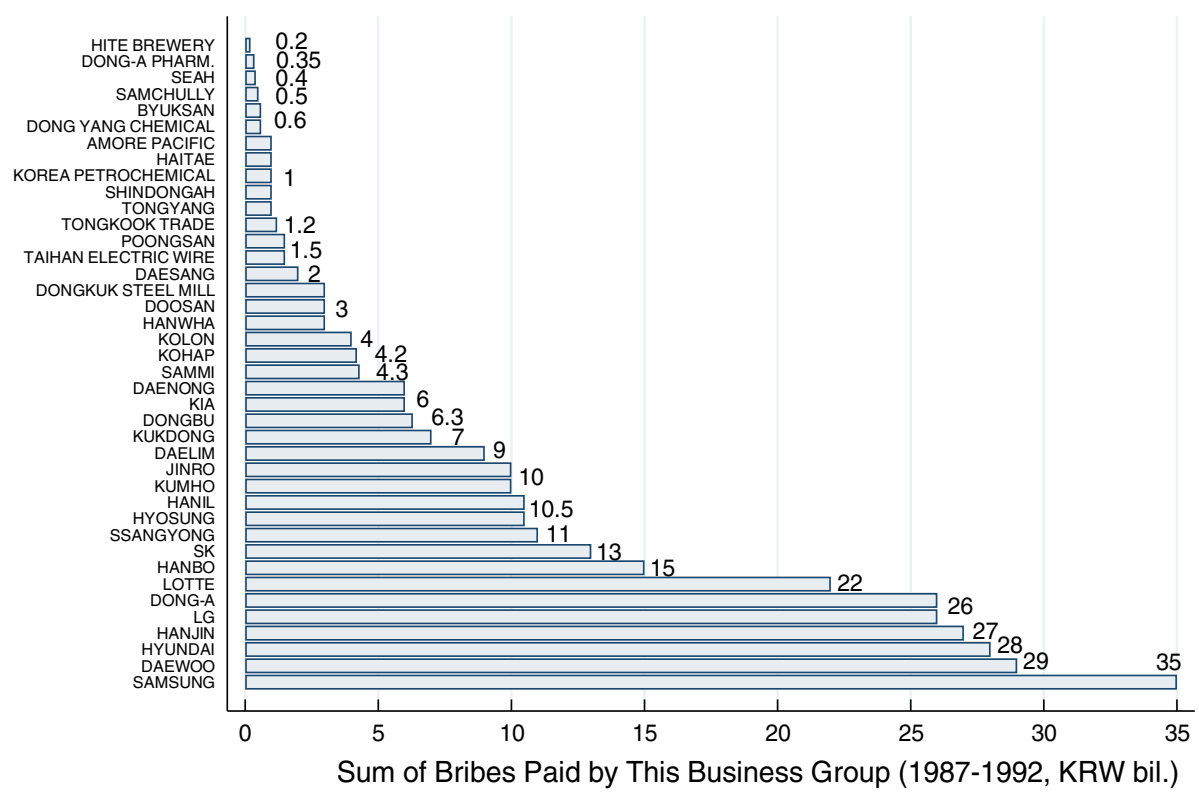

FIGURE 2 Each business group's total amount of bribes

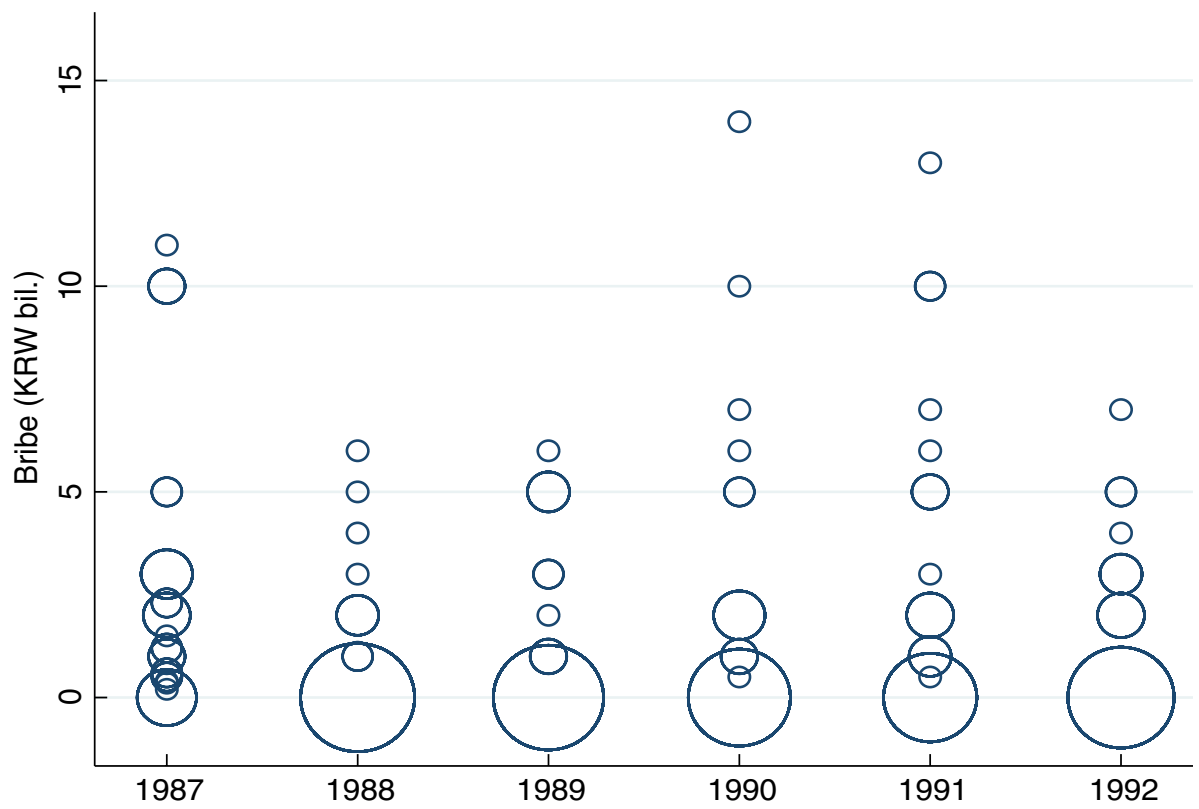

FIGURE 3 Each business group's individual bribe amount by year Note. Each marker in this scatter plot is frequency weighted, thus counts the number of duplicate bribe amount by different business groups at each bribe level in that particular year

\section{3 | Independent variables}

\subsection{1 | Threat of falling high status}

Our hypothesis suggests that those business groups with high status but current-period economic performance not keeping pace with industry peers will pay larger bribes, and the degree of their 
motivation to engage in illicit bribery will also depend on the strength of their socially endowed status. It is important to note in the South Korean context that membership in the high-status category as of 1980 went to business groups that were typically started around 1940 and attained countryleading productivity and profitability by the 1960s and 1970s. Given that they were by far the most productive business groups in South Korea by the early 1980s (Amsden, 1989), their main concern was never with failing economically or even falling to the bottom quartile but with simply falling anywhere into the large middle-status category in which they would not enjoy anywhere near the prior level of access to outside resources.

To test our hypothesis, we construct two measures of "Threat of Falling High Status (Threat of FHS) Definitions 1 and 2" which are the interaction terms between "Bonacich Measures of Status" and "Mediocre ROA Performance." We first measure business groups' social endowment of high status in a given year by their owner-manager family being central in the intergroup marriage network using Bonacich's (1987) centrality score. Bonacich's (1987) $c(\alpha, \beta)$ measure is a commonly used measure for relational data on status (Podolny, 2005). ${ }^{13}$ As summarized in Sauder, Lynn, and Podolny (2012, pp. 274-275), Bonacich's (1987) centrality score considers both the amount of deference received and the extent to which deference is directed. This measure, according to Sauder et al. (2012, p. 274), "is clearly consistent with the view that an actor's status is inherently tied to the status of her associates" and emphasizes "how status leaks or diffuses through relations." We calculate this marriage network-based Bonacich measure of status using the software program UCINET (Borgatti, Everett, \& Freeman, 2002), where the standard setting for the Beta term in calculating the Bonacich measure is $0.995 /$ maxeigen. $^{14}$

Next, we measure "Mediocre ROA Performance" using a dummy that takes the value of one if the business group's ROA performance is between the 25th percentile and the 75th percentile of industry-adjusted and industry-weighted ROA performance relative to peers. Note that we define "Mediocre ROA Performance" in keeping with the local contextual relevance and consistent with prior sociological theory. Local contextual relevance comes from the fact that South Korea since 1964 has focused on the evolving membership of the top 10 list of most successful business groups at both the elite and broader societal levels. From the 1960s until today, government comparisons of these business groups include a focus on who are in the top 10. Also, going back to the 1980s, in South Korea's antitrust law, there is a particular focus on who is in the top 10 . The top 10 is $25 \%$ of the 40 business groups that were expected to give at least a one-time minimal bribe to Chun and Roh. Prior sociological theory also states that elite membership is scarce and tends to fall smaller than middle status membership. Putting these facts together, it is logical that business groups wanted to remain in the top $25 \%$ of performance relative to peers.

Next, consistent with prior sociological theory as well as based on what is readily apparent in the data, the range for mediocre performance is by far the largest, with low performance by those in the bottom 25th quartile, who are so far behind everyone else that they would likely be lacking in

\footnotetext{
${ }^{13}$ Formally, the measure is defined as follows:
}

$$
c(\alpha, \beta)=\alpha \sum_{k=0}^{\infty} \beta^{k} \mathbf{R}^{k+1} \mathbf{1}
$$

where $\alpha$ is a scaling factor, $\beta$ is a weighting factor, $\mathbf{R}$ is a relational matrix, which is 0 along the main diagonal and in which cell $r_{i j}$ summarizes the relative superiority (or inferiority) of group $i$ with respect to group $j$, and 1 is a column vector of ones. For detailed explanations on this measure, see Podolny (2005, pp. 57-58).

${ }^{14}$ During our sample time period, divorce within the elite marriage network was essentially absent. More than a decade after our sample time period, there was a notable divorce involving Samsung. It would be interesting to analyze how divorce impacts social status of elite families, but we are not in a position to analyze the impact of divorce on social status or bribery behavior in this study. 
the resources to even pay a bribe if they wanted to do so. We therefore define "Mediocre ROA Performance" as existing between the 25th and the 75th percentiles of industry-adjusted and industryweighted ROA performance relative to peers. A number of robustness checks show that our results do not change. ${ }^{15}$

Given our status and performance measures, "Threat of FHS Definition 1" is the interaction term between "Bonacich Measure of Status in 1987" (high status measured by the Bonacich centrality in year 1987 marriage network among Korean business groups) and "Middling ROA Performance." "Threat of FHS Definition 2" replaces the term "Bonacich Measure of Status in 1987" in Definition 1 with "Bonacich Measure of Status by Year" (high status measured by the Bonacich centrality in this year's marriage network among Korean business groups). The two measures of "Threat of FHS Definitions 1 and 2" are positively correlated with "Yearly Bribe Paid by Business Group" (0.31 and 0.32 , respectively, both with $p=0.000$ ) at the bivariate levels.

\subsection{2 | Relational ties}

We construct a set of other social network-based indicators to control for their possible influences on the business groups' bribery decisions and amounts. Specifically, we aim to control for the possibility that the formation of close personal ties to politicians either leads business groups to dramatically increase-or reduce - their bribery payments. It is interesting to note that close personal ties could dramatically increase bribery payments if the ties come with an expectation for frequent resource sharing with the politician. Alternatively, close personal ties could decrease bribery payments if the politician is willing to do a favor at a cheaper price for a close personal tie. We thus include a time-varying indicator of whether the business group had at least one marriage tie to a senior government official or politician in a given year ("Marriage Tie to a Senior Gov't Official or Politician by Year"). Also, note that the basis of social networks in South Korea is regional, ${ }^{16}$ with strong ties that develop as a result of attending the same elite regional high school (Siegel, 2007, p. 631). To adjust for these social network-based influences on the business groups' bribery decisions, we include a time-varying indicator of whether owner-manager's family of the business group has a school or marriage tie to Chun or Roh ("Group Has School or Marriage Tie to Chun or Roh by Year"). Table 1 reveals that $57 \%$ of the 40 business groups have at least one immediate political marriage tie and $16 \%$ of those business groups have a school or marriage tie to Chun or Roh during the sample time period.

\footnotetext{
${ }^{15}$ Our results are robust (a) to further controlling for the top quartile of performance and the interaction of high status and top quartile performance; (b) to having the "Threat of FHS Definition 2" variable temporarily include the mere four group-year observations out of 237 of a firm with status in the top quartile and relative performance below the 25th percentile, (c) to having the "Threat of FHS Definition 2" variable temporarily include the one single group-year observation with status $>5$, which is an alternative cutoff for yet higher status and performance in the bottom quartile, (d) to controlling for each quartile of performance and status interacted with each quartile of performance (where the bottom quartile is the omitted category to be the reference set), (e) to temporarily expanding the "Mediocre ROA Performance" by an observation at both the bottom and upper ends, (f) and (g) temporarily substituting the "Threat of FHS Definition 2" variable and using alternatively a continuous interaction term of status and relative performance and limiting the sample to the just over 175 observations with values of the interaction term between -0.5 and 0.5 , and with the somewhat smaller number of observations with values of the interaction term between -0.1 and 0.1 , and (h) to using that same continuous interaction term for status $\times$ relative performance, including the full sample, and partialing out the effect of dummy variables for (status $\times$ relative performance) being less than -0.5 and larger than 0.5 .

${ }^{16}$ Regional origin is a time-invariant group characteristic and therefore gets absorbed as part of the group fixed effects. Regional enmity stemming from political rivalry and oppression long existed between Koreans from the Jeolla (southwest, the oppressed) and the Gyeongsang (southeast, the oppressing) regions. For a description of South Korean political networks, see Siegel (2007, pp. 631-634).
} 


\subsection{3 | Financial and industry characteristics}

We also control for a number of financial and industry characteristics of the business groups as such characteristics could have the potential to be alternatively driving the group-level motivation, resource availability, and incentive to engage in corporate bribery. Prior studies of corruption (e.g., Chavis, 2013; Martin et al., 2007; Svensson, 2003; Van Vu, Tran, Van Nguyen, \& Lim, 2016) suggest that one's cash flow profitability (ROA), firm size, leverage, financial constraint, and financial standing relative to peers could have independent effects on the bribery decision. We thus construct and fully control for "Group ROA by Year" (total group operating profit/total group assets), "Log of Group Assets by Year," "Group Leverage by Year," and "Industry-adjusted and -weighted Group Portfolio ROA by Year" (each business group's average industry-adjusted and -weighted ROA calculated by first taking each affiliate's ROA relative to its four-digit industry ROA performance, and then weighting by the relative assets by industry of the business group's affiliates, so that anything below zero means that the group is behind its industry peers). The last control variable is centered at its own sample mean so that we could do a robustness check in which we examine its squared term and remove any possible collinearity concern between those two control variables and the set of other control variables listed in the next paragraph. (The results are the same with and without the centering of this control variable.)

As discussed earlier, we also control for "Export Intensity," "Advertising Intensity," "R\&D Intensity," and "Training Expenditure Intensity." They are mean-centered variables which are constructed as a percentage of total sales in that particular year and then centered at their own sample means. ${ }^{17}$ Because the typical expenditure on training is very small, "Training Expenditure Intensity" is scaled by multiplying its percentage term by 1,000 before centering it at its sample mean. Note that regardless of centering these variables at their means, the results are substantively identical with or without mean-centering, and doing so simply reduces the possibility of any collinearity concern among these particular control variables. As a robustness check to assess the significance of "Threat of FHS" in consideration of industry concentration, we also calculate each business group's assetweighted industry Herfindahl ("Asset-weighted Industry Herfindahl”) at different industry digit levels. Specifically, we first take each industry's Herfindahl measure using data from NICE, and then calculate each business group's asset-weighted Herfindahl by accounting for the distribution of each group's asset portfolio across industries in each year. Industry is defined alternatively at the two-digit, three-digit, four-digit, and five-digit levels based on the Korea Standard Industry Classification codes.

\section{4 | Method}

We examine the relationship between the bribe amounts paid by business groups and the threat of falling high status using a fixed-effects Poisson quasi-maximum likelihood estimator (QMLE) panel regression with cluster-robust standard errors that allow heteroskedasticity and within-cluster error correlation. The unit of analysis in our regressions is "business group-year" and standard errors are clustered at the business group level. ${ }^{18}$ Consistent with Gourieroux, Monfort, and Trognon (1984), Santos Silva and Tenreyro (2006), and Wooldridge (2010, pp. 740-741), we use this method as it is

\footnotetext{
${ }^{17}$ Note that we centered these variables, even though none of them causes a collinearity issue for our main variable of interest, to address any concern about a potential collinearity issue among the four control variables themselves. As part of our robustness checks, we have also included the squared terms of these four controls. Centering those control variables, while not impacting our variable of interest in any way, was also a way of making sure that the robustness check did not suffer from collinearity among the control variables and their squared terms.

${ }^{18}$ We note that as discussed in Siegel and Larson (2009) and shown in Stock and Watson (2008), we have more than sufficient degrees of freedom and are using the right estimator with clustering (Hansen, 2007).
} 
particularly well suited for non-count data with both a meaningful percentage of true zero values and relatively few distinct values for the dependent variable as well as we wish to condition out any time-invariant unobserved heterogeneity that is difficult to measure. Notably, this method generates consistent estimates under the weak assumption that only the conditional mean be correctly specified. This tells that the distribution of the outcome variable given a set of covariates does not need to be Poisson distributed (Cameron \& Trivedi, 2015, p. 234; Santos Silva \& Tenreyro, 2006, p. 645; Wooldridge, 2010, pp. 727-728). Poisson QMLE also does not require the well-known equality of mean and variance property, allowing the conditional variance of the outcome variable to be almost anything (Wooldridge, 1997, pp. 355-358), and particularly, the outcome variable does not need to be a count variable (Wooldridge, 2010, p. 728). Since the most common mean function in applications is the exponential, which is the default for the Poisson model, we estimate the following conditional mean form of the fixed-effects Poisson QMLE regression:

$$
E\left[y_{i t} \mid \alpha_{i}, X_{i t}\right]=\alpha_{i} \cdot \exp \left(X_{i t} \beta\right)
$$

where $y_{i t}$ is the dependent variable that is the bribery amount paid by business group $i(1, \ldots, 40)$ in year $t(1987, \ldots, 1992), X_{i t}$ are the covariates. They include our key independent variable ("Threat of FHS Definitions 1 and 2"), its main effects ("Bonacich Measure of Status by Year" and "Mediocre ROA Performance by Year"), and a set of control variables that capture relational ties ("Marriage Tie to a Senior Gov't Official or Politician by Year" and "Group Has School or Marriage Tie to Chun or Roh by Year") and financial characteristics of the business groups ("Group ROA by Year," "Industry-adjusted and -weighted Group Portfolio ROA by Year," "Log of Group Assets by Year," "Group Leverage by Year," "Advertising Intensity," "Export Intensity," "R\&D Intensity," and "Training Expenditure Intensity"), and year dummies that allow us to control for the average effects of specific time periods and help alleviate bias from overall trends and events that occurred at a specific time which might have influenced the bribery amount paid by business group. $\beta$ are the coefficients to be estimated, and $\alpha_{i}$ are time-invariant, group-specific effects. ${ }^{19}$

\section{5 | RESULTS}

As part of our initial exploratory data analysis, we contrast the yearly average of the total bribe amounts of groups under threat of falling high status with that of groups not under such threat over the sample time period in Figure 4. As visually illustrated, the groups under threat of falling high status pay larger bribes on average across all years. We further examine this bivariate relationship between threat of falling high status and bribery using a nonparametric $\chi^{2}$ test and report the result in Table 2, where we modify "Threat of FHS Definition 2" as a dummy which takes the value of one if the variable has a positive value; otherwise, zero. As shown in Table 2, the propensity to bribe for groups under threat of falling high status is $63 \%$ vs. $36 \%$ for groups not under such threat. The difference in the propensity to bribe between the two groups is $27 \%(p=0.000)$, which suggests a statistically meaningful effect of threat of falling high status on the business groups' bribery decisions.

\footnotetext{
${ }^{19}$ Note that Poisson QMLE standard errors are robust to overdispersion that occurs when the conditional variance of an outcome variable exceeds the conditional mean. Data with presence of overdispersion are commonly analyzed using negative binomial regression, but the conditional negative binomial model for panel data has been known as not a true fixed-effects analysis (Allison \& Waterman, 2002; Greene, 2007) and to suffer from the well-known "incidental parameters problem," which is not an issue for a fixed-effects Poisson model (Greene, 2007; Lancaster, 2000). We thus do not consider such alternative as an option. Likewise, a linear regression model is inadequate to fit our data because the distribution of residuals will be heteroscedastic non-normal. Tobit regression also requires a crucial assumption of the normality of the errors. Although our results do not change when we use a Tobit regression, the post-regression conditional moment tests reject the null of normal errors, suggesting that Tobit is not the appropriate model.
} 


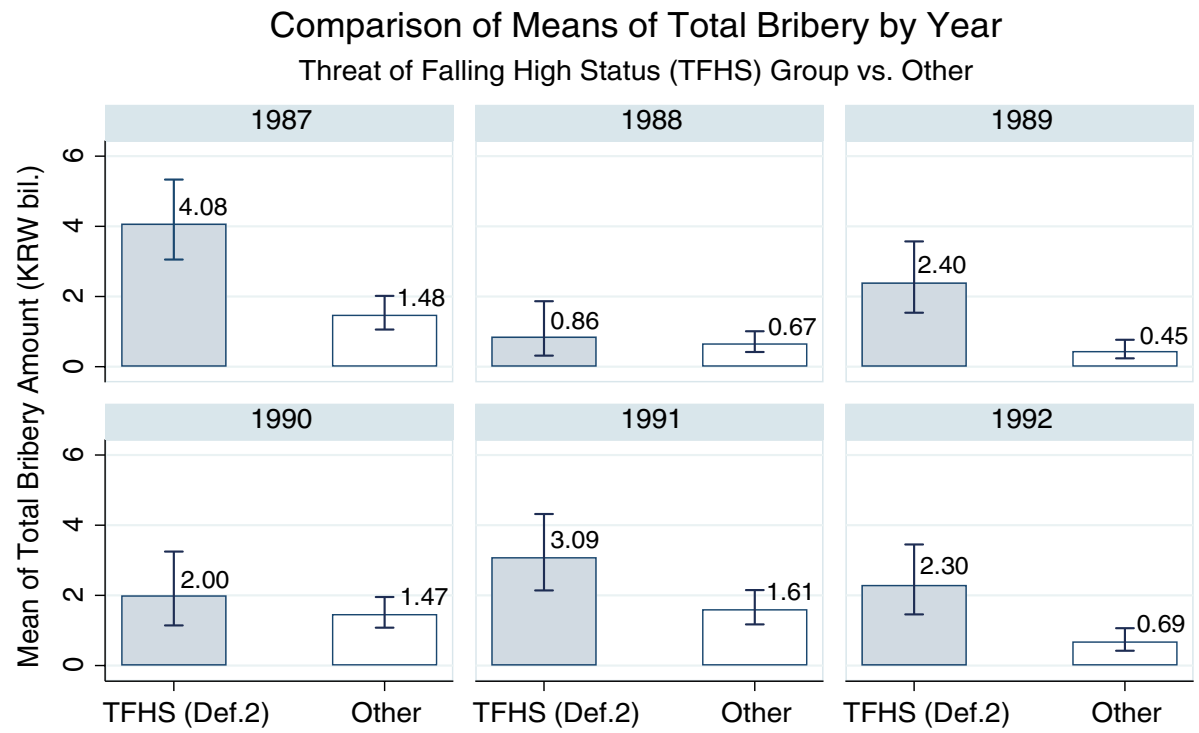

H Upper Confidence Limit (95\%)/Lower Confidence Limit (95\%)

FIGURE 4 Do business groups under threat of falling high status pay larger bribes?

Notes. TFHS (Def.2) indicates high status in this year's marriage network among Korean business groups interacted with mediocre economic performance. Other indicates the group not categorized as TFHS

TABLE $2 \chi^{2}$ test of association between threat of falling high status and bribery

\begin{tabular}{llll} 
& \multicolumn{2}{c}{ Bribe } & Total \\
\cline { 2 - 4 } Threat of Falling High Status $^{\mathbf{a}}$ & Yes & No & 59 \\
\hline Yes & 37 & 22 & $(37.29)$ \\
(row percent) & $(62.71)$ & 114 & 178 \\
No & 64 & $(64.04)$ & 136 \\
(row percent) & $(35.96)$ & & 237 \\
Total & 101 & $12.973(\operatorname{Pr}=0.000)$ &
\end{tabular}

Notes. $\mathrm{H}_{0}$ : There is no association between threat of falling high status and bribery by business group.

${ }^{a}$ Dummy which takes the value of one if Threat of Falling High Status Definition 2 has a positive value; otherwise, zero.

Next, we further explore the relationship between bribery and relative performance by status using Figures 5 and 6. Figure 5 plots that relationship for high status groups in the 75th percentile for our marriage-tie based status, together with the boundary of relative performance identified as threatening high status. Figure 6 plots the same for those whose status ranges between the 50th and the 75 th percentiles. Figure 5 alone suggests that high status groups facing the current-time mediocre performance (inside the vertical dot lines) tend to pay larger bribes than those not (outside the vertical dot lines). In comparison to Figure 6, Figure 5 also demonstrates that the higher the status, the larger the bribery payment is among the groups who have at least one inter-business group marriage ties (status $>0$ ). Altogether, our exploratory data analysis points us to the next step of examining our threat of falling high status hypothesis in a multivariate context.

Table 3 reports the Poisson QMLE panel regression results with group and year fixed effects and robust standard errors clustered by business groups. Model (1) shows the baseline result without 


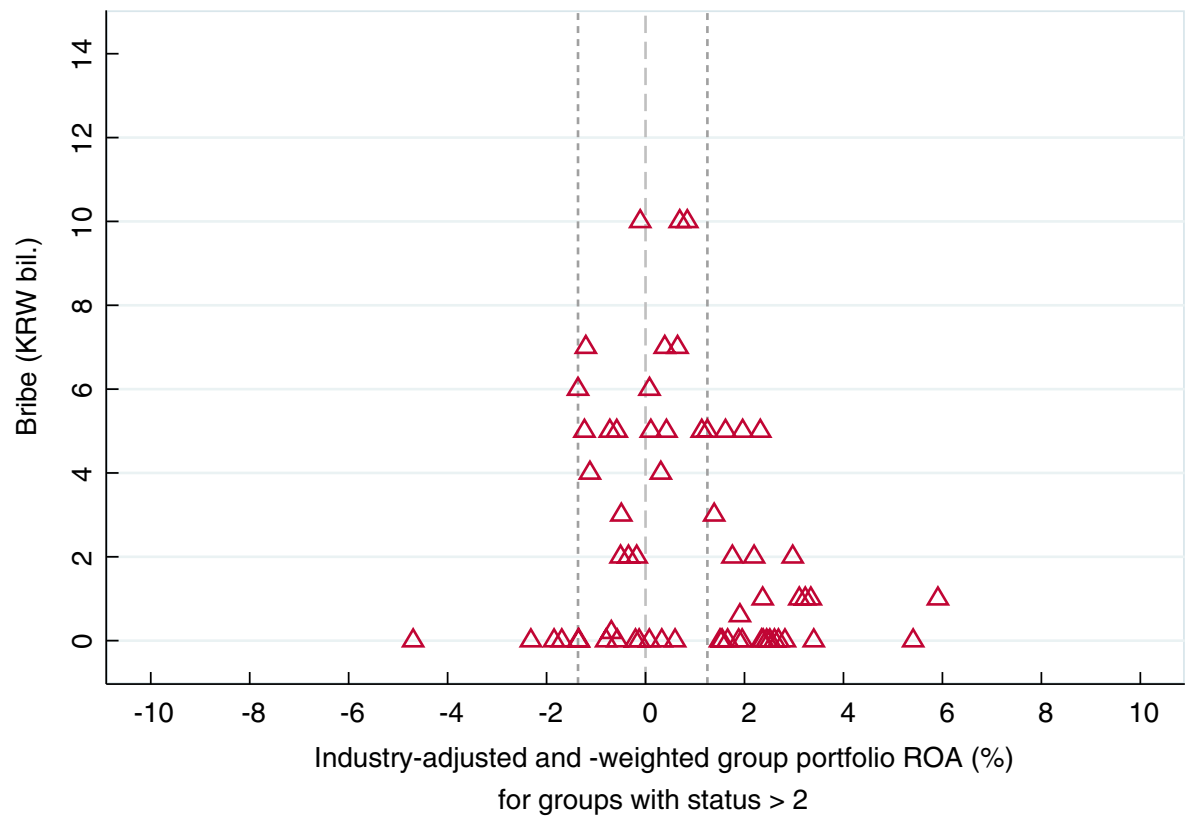

FIGURE 5 Business groups' relative financial performance and bribery for groups whose status based on Bonacich measure of status is above the 75th percentile (status $>2, \mathrm{~N}=62,1987-1992)$. Vertical dot lines indicate the boundary of relative ROA performance identified as threatening high status

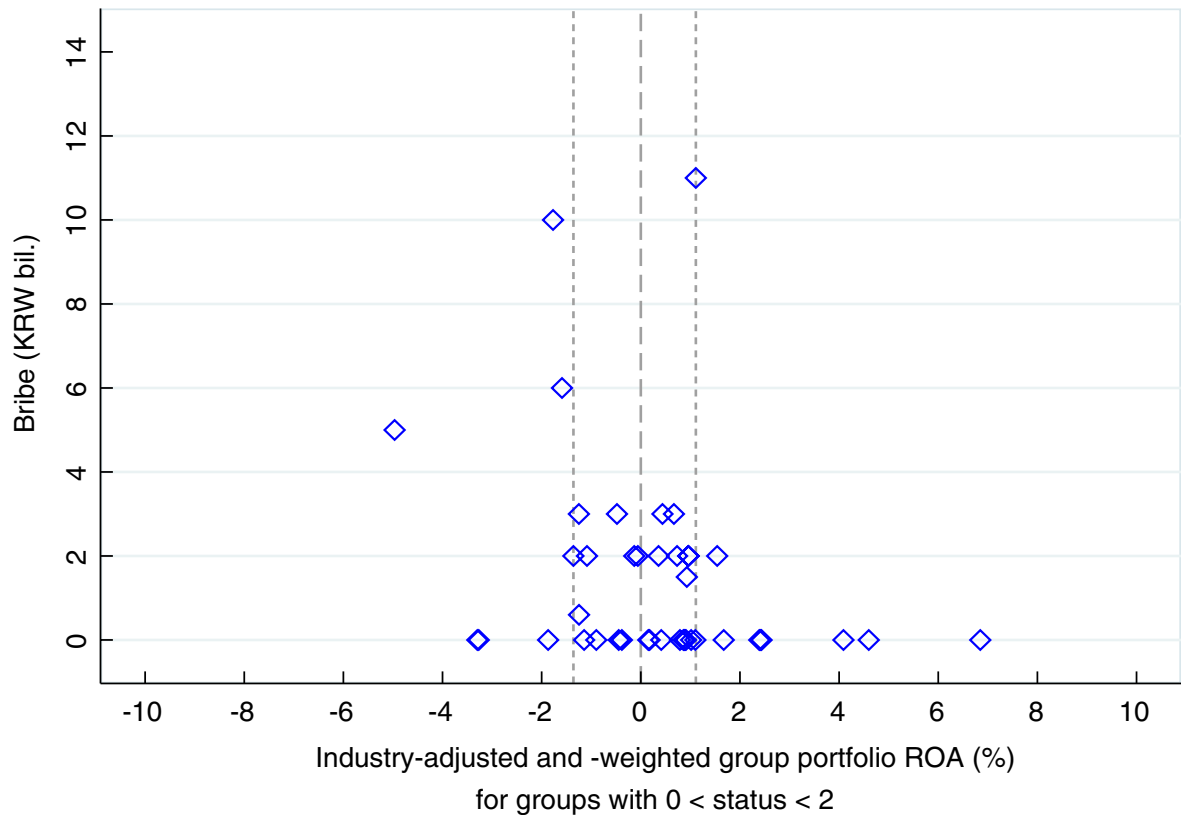

FIGURE 6 Business groups' relative financial performance and bribery for groups with Bonacich measure of status is in between the 50th and the 75th percentiles $(0<$ status $<2, \mathrm{~N}=42,1987-1992)$ 
TABLE 3 Poisson QMLE regressions with group fixed effects and clustered standard errors for panel data (1987-1992)

\begin{tabular}{|c|c|c|c|c|c|}
\hline $\begin{array}{l}\text { Dependent variable: Yearly } \\
\text { Bribe } \\
\text { Paid by Business Group }\end{array}$ & (1) & (2) & (3) & $\begin{array}{c}\text { (4) } \\
\text { Threat of FHS } \\
\text { Definition } 1^{\mathrm{a}}\end{array}$ & $\begin{array}{c}\text { (5) } \\
\text { Threat of FHS } \\
\text { Definition } 2^{\mathbf{b}}\end{array}$ \\
\hline $\begin{array}{l}\text { Threat of Falling High Status } \\
\text { (FHS) }\end{array}$ & & & & $\begin{array}{r}0.163(0.087) \\
{[0.062]}\end{array}$ & $\begin{array}{r}0.164(0.081) \\
{[0.043]}\end{array}$ \\
\hline $\begin{array}{l}\text { Bonacich Measure of Status by } \\
\quad \text { Year }\end{array}$ & & & $\begin{array}{r}-0.130(0.153) \\
{[0.393]}\end{array}$ & (See note $C$ ) & $\begin{array}{r}-0.247(0.168) \\
{[0.142]}\end{array}$ \\
\hline $\begin{array}{l}\text { Mediocre ROA Performance by } \\
\text { Year }\end{array}$ & & $\begin{array}{r}-0.151(0.226) \\
{[0.504]}\end{array}$ & & $\begin{array}{r}-0.351(0.275) \\
{[0.202]}\end{array}$ & $\begin{array}{r}-0.407(0.284) \\
{[0.152]}\end{array}$ \\
\hline $\begin{array}{l}\text { Group Has School or Marriage } \\
\text { Tie to Chun or Roh by Year }\end{array}$ & $\begin{array}{r}-11.673(1.110) \\
{[0.000]}\end{array}$ & $\begin{array}{r}-11.719(1.125) \\
{[0.000]}\end{array}$ & $\begin{array}{r}-11.840(1.153) \\
{[0.000]}\end{array}$ & $\begin{array}{r}-11.917(1.127) \\
{[0.000]}\end{array}$ & $\begin{array}{r}-12.123(1.163) \\
{[0.000]}\end{array}$ \\
\hline $\begin{array}{l}\text { Marriage Tie to a Senior Gov't } \\
\text { Official or Politician by Year }\end{array}$ & $\begin{array}{r}-1.158(0.356) \\
{[0.001]}\end{array}$ & $\begin{array}{r}-1.231(0.402) \\
{[0.002]}\end{array}$ & $\begin{array}{r}-1.105(0.408) \\
{[0.007]}\end{array}$ & $\begin{array}{r}-1.109(0.529) \\
{[0.036]}\end{array}$ & $\begin{array}{r}-1.044(0.621) \\
{[0.092]}\end{array}$ \\
\hline Group ROA by Year & $\begin{array}{r}0.071(0.104) \\
{[0.494]}\end{array}$ & $\begin{array}{r}0.072(0.103) \\
{[0.484]}\end{array}$ & $\begin{array}{r}0.073(0.104) \\
{[0.484]}\end{array}$ & $\begin{array}{r}0.066(0.099) \\
{[0.508]}\end{array}$ & $\begin{array}{r}0.068(0.098) \\
{[0.487]}\end{array}$ \\
\hline $\begin{array}{l}\text { Industry-adjusted and } \\
\text {-weighted Group Portfolio } \\
\text { ROA by Year }\end{array}$ & $\begin{array}{r}-0.053(0.066) \\
{[0.426]}\end{array}$ & $\begin{array}{r}-0.045(0.071) \\
{[0.524]}\end{array}$ & $\begin{array}{r}-0.057(0.066) \\
{[0.387]}\end{array}$ & $\begin{array}{r}-0.006(0.081) \\
{[0.943]}\end{array}$ & $\begin{array}{r}0.000(0.080) \\
{[0.996]}\end{array}$ \\
\hline Log of Group Assets by Year & $\begin{array}{r}0.021(0.267) \\
{[0.938]}\end{array}$ & $\begin{array}{r}0.068(0.268) \\
{[0.799]}\end{array}$ & $\begin{array}{r}-0.050(0.262) \\
{[0.850]}\end{array}$ & $\begin{array}{r}0.092(0.271) \\
{[0.736]}\end{array}$ & $\begin{array}{r}0.005(0.265) \\
{[0.985]}\end{array}$ \\
\hline Group Leverage by Year & $\begin{array}{r}-0.655(1.254) \\
{[0.601]}\end{array}$ & $\begin{array}{r}-0.488(1.275) \\
{[0.702]}\end{array}$ & $\begin{array}{r}0.148(1.730) \\
{[0.932]}\end{array}$ & $\begin{array}{r}-0.433(1.256) \\
{[0.730]}\end{array}$ & $\begin{array}{r}0.495(1.689) \\
{[0.769]}\end{array}$ \\
\hline Advertising Intensity by Year & $\begin{array}{r}0.207(0.473) \\
{[0.661]}\end{array}$ & $\begin{array}{r}0.222(0.461) \\
{[0.631]}\end{array}$ & $\begin{array}{r}0.157(0.488) \\
{[0.748]}\end{array}$ & $\begin{array}{r}0.226(0.455) \\
{[0.619]}\end{array}$ & $\begin{array}{r}0.220(0.469) \\
{[0.639]}\end{array}$ \\
\hline Export Intensity by Year & $\begin{array}{r}-0.010(0.009) \\
{[0.253]}\end{array}$ & $\begin{array}{r}-0.009(0.010) \\
{[0.363]}\end{array}$ & $\begin{array}{r}-0.011(0.009) \\
{[0.223]}\end{array}$ & $\begin{array}{r}-0.009(0.010) \\
{[0.412]}\end{array}$ & $\begin{array}{r}-0.008(0.011) \\
{[0.452]}\end{array}$ \\
\hline R\&D Intensity by Year & $\begin{array}{r}0.083(1.325) \\
{[0.950]}\end{array}$ & $\begin{array}{r}0.021(1.332) \\
{[0.988]}\end{array}$ & $\begin{array}{r}0.033(1.395) \\
{[0.981]}\end{array}$ & $\begin{array}{r}0.221(1.342) \\
{[0.869]}\end{array}$ & $\begin{array}{r}0.297(1.396) \\
{[0.832]}\end{array}$ \\
\hline $\begin{array}{l}\text { Training Expenditure Intensity } \\
\text { by Year }\end{array}$ & $\begin{array}{r}-0.211(0.349) \\
{[0.546]}\end{array}$ & $\begin{array}{r}-0.192(0.344) \\
{[0.576]}\end{array}$ & $\begin{array}{r}-0.234(0.364) \\
{[0.521]}\end{array}$ & $\begin{array}{r}-0.226(0.318) \\
{[0.477]}\end{array}$ & $\begin{array}{r}-0.230(0.307) \\
{[0.454]}\end{array}$ \\
\hline Constant & $\begin{array}{r}2.703(6.036) \\
{[0.654]}\end{array}$ & $\begin{array}{r}1.735(5.945) \\
{[0.770]}\end{array}$ & $\begin{array}{r}4.938(6.093) \\
{[0.418]}\end{array}$ & $\begin{array}{r}-0.487(6.474) \\
{[0.940]}\end{array}$ & $\begin{array}{r}3.343(6.197) \\
{[0.590]}\end{array}$ \\
\hline Business Group Fixed Effects & Yes & Yes & Yes & Yes & Yes \\
\hline Year Fixed Effects & Yes & Yes & Yes & Yes & Yes \\
\hline Pseudo $\mathrm{R}^{2}$ & 0.428 & 0.429 & 0.429 & 0.433 & 0.436 \\
\hline $\mathrm{N}$ & 237 & 237 & 237 & 237 & 237 \\
\hline
\end{tabular}

Notes. Poisson quasi-maximum likelihood estimator panel regressions where robust standard errors clustered by business groups are reported in parentheses and $p$-values are reported in square brackets.

${ }^{a}$ Bonacich Measure of Status in 1987 (high status measured by the Bonacich centrality in year 1987 marriage network among Korean business groups) $\times$ Mediocre ROA Performance (dummy that takes the value of one if the business group's ROA performance is between the 25th percentile and the 75th percentile of industry-adjusted ROA performance relative to peers).

${ }^{\mathrm{b}}$ Bonacich Measure of Status by Year (high status measured by the Bonacich centrality in this year's marriage network among Korean business groups) $\times$ Mediocre ROA Performance (dummy that takes the value of one if the business group's ROA performance is between the 25th percentile and the 75 th percentile of industry-adjusted ROA performance relative to peers).

${ }^{\mathrm{c}}$ Threat of FHS Definition 1 is a cross-sectional measure for Year 1987 and therefore gets automatically absorbed as part of the group fixed effects included in this model. 
any "Threat of FHS Definition" and its two main effects ("Bonacich Measure of Status by Year" and "Mediocre ROA Performance by Year"). In Models (2) and (3), we add each of the two main effects of "Threat of FHS Definition." As shown, neither of the two main effects is statistically meaningful. In Models (4) and (5), however, where we show the results of the two "Threat of FHS Definitions 1 and 2," we find that each coefficient of the two definitions is positively associated with bribery amounts. It is noteworthy that the precision of our estimates is particularly good given the degrees of freedom and the comprehensive control variables we use. Of the two measures, it is logical that "Threat of FHS Definition 2," which is the one that fully reflects status change over time, is the more statistically meaningful variable on account of its reflecting status change over time. Overall, this supports our hypothesis that firms with a large social endowment of high status but under the threat of an impending fall in status due to current-time mediocre economic performance relative to industry peers pay larger bribes, all else being equal. In particular, in Model (5) of Table 3, the coefficient of "Threat of FHS Definition 2" means that for a one unit change in "Threat of FHS Definition 2," the difference in the logs of expected counts is expected to increase by 0.164 , holding the other covariates in the model constant at their means. Take the example starting with the dependent variable at its mean; then holding all other variables constant, a one standard deviation increase in "Threat of FHS Definition 2" is associated with 2.59 billion won (\$3 million) in additional annual bribes, which is economically meaningful.

Table 3 also shows that forming a marriage tie with a senior government official or politician and forming a close social tie to Chun or Roh are associated with a decrease in bribes $(p=0.000$ and 0.092, respectively in Model 5). A possible explanation is that having a close tie with Chun or Roh or a senior government official leads to a very different relationship with the government elite. Instead of needing to pay transactional payments to someone like Chun or Roh, the close social tie to Chun or Roh may well facilitate a form of co-ownership in which profit sharing replaces bribery as the method of resource sharing. The fact that under co-ownership, profit sharing may replace the transactional payments known as bribery, is a prediction of Shleifer and Vishny (2002). We also report that none of the control variables that capture the business groups' financial characteristics is statistically notable in Table 3. All in all, our findings suggest that the fact that the effect of status by itself or mediocre performance by itself is not statistically meaningful implies that neither is driving the results alone. Instead, the result suggests that it is the time-varying condition of having a legacy of high status but dealing with current-period mediocre performance relative to peers that drives the decision of how much in bribes to pay. This is consistent with our thesis of the threat of falling high status, where it takes a combination of resources (status), need (the clear possibility of falling out of high status in the future), and opportunity (the belief that bribery will lead to government-provided resources that can be quickly invested in market capabilities and help the group to return to secure high status).

Next, inspired by the work of Ades and Di Tella (1999), which proposed that increased industrial competition could bring down bribes, we take Table 3 and run Model (5) with the alternative group-asset-weighted Herfindahls ("Asset-weighted Industry Herfindahl”) described earlier. Panel A of Table 4 shows that not only is the "Threat of FHS Definition 2" robust to including alternative Herfindahls based on different specificity of industry definition, but also that industrial competition as proxied by the Herfindahl measure is not by itself a consistent or statistically meaningful predictor of corporate bribery. Next, we further control for a panel measure for low status ("Low Status" dummy), which takes the value of one if a business group has no inter-business group marriage ties by that particular year. As prior literature (e.g., Phillips \& Zuckerman, 2001) indicates, low-status firms break social rules because they see nothing further to lose from doing so. At the same time, low-status firms may lack the financial resources to be able to engage in bribery. Whether they are 


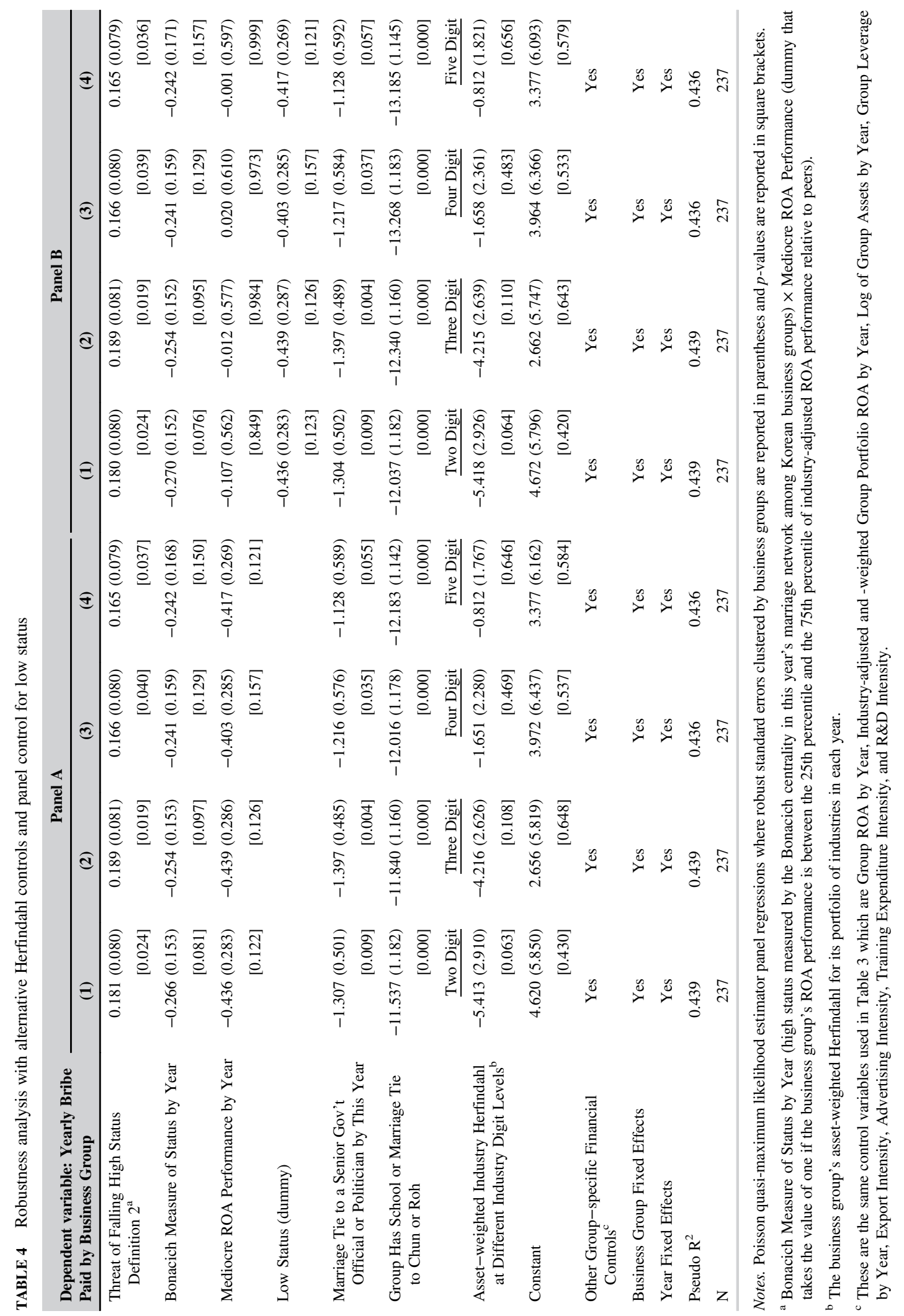




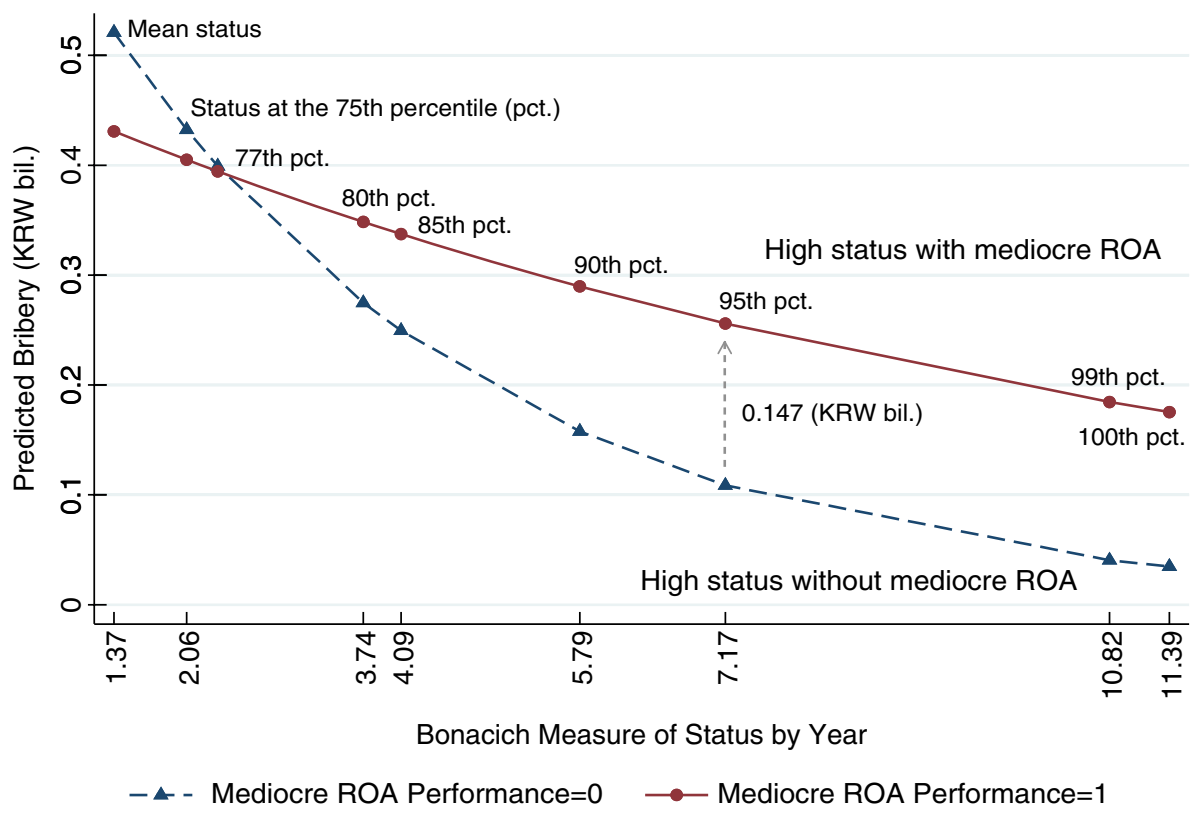

FIGURE 7 Threat of falling high status. Note. This figure was created based on Model 1 of Panel B in Table 4 to illustrate above-mean status in this year's marriage network among Korean business groups interacted with mediocre current-time economic performance, holding everything else in the model at its mean

so severely financially constrained that they lack the money to engage in bribery is ultimately an empirical question - since bribery is not exactly as resource-intensive as building a large-scale R\&D capability. Thus, it is worthwhile to at least explicitly rule in or rule out whether there is a low-status-specific determinant of bribery that is distinct from high status under threat of falling. Panel B of Table 4 shows that our main results are robust to controlling for whether low-status business groups might have paid bribes at a different rate. Lastly, we also note that our main results are robust to alternatively using negative binomial specifications, and do not change when we subtract the amounts that groups gave to key quasi foundations from the dependent variable.

Finally, we implement steps to further test the interaction effect of interest in its nonlinear specification. We adopt a simple and rigorous recentering approach proposed by Jeong, Siegel, and Chen (2017) based on Greene (2010) and other statisticians' advice and implement the following steps. First, we plot the predicted bribery amounts against status with and without current-period mediocre ROA performance, holding everything else in the model at its mean, using the most rigorous model where we further control for both industry and low-status influences (Model 1 of Panel B, Table 4). As seen in Figure 7, there is a notable visual difference in terms of bribes when going from high status without current-period mediocre ROA performance to high status with current-period mediocre ROA performance. Second, we recenter the status variable ("Bonacich Measure of Status by Year") at the status percentile of interest, rerun the same Poisson QMLE regression model, and then look at the coefficient of "Mediocre ROA Performance" to ascertain (as shown in Table 4) that there is a statistically meaningful difference between high status with and without current-period mediocre ROA performance. Third, we calculate the predicted bribery amounts and the economic significance of the threat of falling high status at the status percentile of interest. As shown in Table 6, the predicted size of bribery (technically, the incidence rate of large-scale bribery) increases by economically meaningful amounts when high-status firms experience current-period mediocre ROA performance. 
TABLE 5 The statistically meaningful difference in going from high status to threat of falling high status

\begin{tabular}{lll} 
Status Level (Bonacich Measure of Status by Year) & Z-statistic & $\boldsymbol{p}>\mathbf{I Z |}$ \\
\hline Recentered at the max. value of 11.393 & 2.27 & 0.023 \\
Recentered at the 99th percentile of 10.824 & 2.27 & 0.024 \\
Recentered at the 95th percentile of 7.174 & 2.16 & 0.031 \\
Recentered at the 90th percentile of 5.791 & 2.01 & 0.044 \\
\hline
\end{tabular}

Notes. This table was created based on Model 1 of Panel B in Table 4 to show that there is a statistically meaningful difference in going from high status to threat of falling high status at the 90th percentile and higher. The method employed is to recenter the status variable at the percentile of interest, and then to run this model with the recentered status variable each time, and then to utilize the $p$ value associated with the Mediocre ROA Performance variable as the indicator of the effect of going from high status to falling high status at each level of high status. We use this model because this is an emerging economy in which groups are not highly specialized at the granular industry level and are likely to be foremost focused on the concentration level within their two-digit industry sector. Nevertheless, we see substantially similar results using the alternative models in Table 4.

TABLE 6 Predicted bribe amount at the status percentile of interest

\begin{tabular}{|c|c|c|c|c|c|c|}
\hline $\begin{array}{l}\text { Predicted } \\
\text { bribe amount } \\
\text { (KRW bil.) }\end{array}$ & $\begin{array}{l}\text { Difference in predicted } \\
\text { bribe amount going from } \\
\text { high status to threat of } \\
\text { FHS2 at each status level }\end{array}$ & $\begin{array}{l}\text { Threat of FHS2 } \\
\text { (Bonacich Measure } \\
\text { of Status by Year x } \\
\text { Mediocre ROA } \\
\text { Performance) }\end{array}$ & $\begin{array}{l}\text { Mediocre } \\
\text { ROA } \\
\text { Performance }\end{array}$ & \multicolumn{2}{|c|}{$\begin{array}{l}\text { Bonacich Measure } \\
\text { of Status by Year }\end{array}$} & $\begin{array}{l}\text { All other variables } \\
\text { at sample mean }\end{array}$ \\
\hline 0.035 & 0.141 & 0 & 0 & Max value & 11.393 & Yes \\
\hline 0.175 & & 11.393 & 1 & & & \\
\hline 0.041 & 0.144 & 0 & 0 & 99th percentile & 10.824 & Yes \\
\hline 0.185 & & 10.824 & 1 & & & \\
\hline 0.109 & 0.147 & 0 & 0 & 95th percentile & 7.174 & Yes \\
\hline 0.256 & & 7.174 & 1 & & & \\
\hline 0.158 & 0.132 & 0 & 0 & 90th percentile & 5.791 & Yes \\
\hline 0.290 & & 5.791 & 1 & & & \\
\hline
\end{tabular}

Notes. This table shows that a shift to mediocre ROA performance predicts the biggest boost in predicted annual bribe amount if a firm is a high status firm (shown here for the 90th percentile and higher). Thus this provides the evidence of threat of falling high status leading to more bribery. Note that a shift to mediocre performance does not increase bribes for firms with low status. The simulation is based on Model 1 of Panel B in Table 4.

\section{6 | CONCLUSION}

We find that, controlling for a range of alternative explanations, threat of falling high status - that is, longstanding high social status threatened by current-period economic performance lagging behind that of industry peers-is an economically and statistically meaningful predictor of largescale corporate bribery. Our findings suggest that following the threat of falling high status, firms, historically on the strength of social endowment and economic performance, tend to respond to such threat by engaging in large-scale bribery as a nonmarket strategy and pay larger bribes than all other firms, ceteris paribus. This is particularly relevant in an institutional environment where bribery and rule-breaking occur because the market and prevailing institutions reward both sufficiently and punish them insufficiently. Our theory and findings also suggest that the concept of status in economics and sociology can be extended and moderately reformulated to help explain an important dimension of social deviance, large-scale corporate bribery. This study is among the first, if not the first, to show explicitly how the social-network dynamics of status contribute to firms' illegal activity (in this case, payment of bribes to senior-level government officials). We aim to contribute to the burgeoning nonmarket-strategy literature and to micro-empirical research on causes of corruption. 
In the absence of an instrumental variable or exogenous shock, there is always at least the possibility of simultaneity and feedback. That said, our evidence supports our prediction that highly endowed social status interacted with mediocre economic performance is positively correlated with an increase in the amount of bribery. The precision of our estimates of "Threat of Falling High Status Definitions 1 and 2" is notable particularly given the degrees of freedom we have and comprehensive control variables we use. Further precision of those estimates is not possible given our sample size despite the fact that those 40 business groups represent a very high percentage of the total value-added in South Korea.

Our findings about threat of falling high status can also be useful to those interested in how institutions might be used to reduce bribery and its negative social-welfare effects. To the extent that law enforcement and the media face resource constraints in monitoring companies, it pays to know which types of companies should be most closely monitored, and under which types of conditions. It may make sense to concentrate on measuring relative company status in a dynamic sense, and on examining whether the threat of falling high status leads companies to increase their reliance on large-scale bribery.

South Korea is not an idiosyncratic test case. It is representative of a large number of third-wave democracies, also known as emerging or transition economies. The political scientist Samuel P. Huntington distinguished three modern waves of democratization; during the third wave, extending from the mid-1970s into the 1990s (Huntington, 1991), over 65 new democracies emerged across the world (Møller \& Skaaning, 2013, p. 99), South Korea's among them. Because South Korea's democratization preceded that of numerous other countries, it provides some leading indicators of how democratization changes business and society. Political scientists actively study the 1987-1992 time period, at the heart of third-wave democratization, in an effort to predict subsequent sociopolitical developments (Møller \& Skaaning, 2013); the political science literature has identified a number of common patterns. Our theory and evidence offer insights and policy implications on large-scale corporate bribery pertinent to the approximately 65 emerging economies whose institutional contexts resemble South Korea's during its pre-democratization and early democratization periods, and to some extent also to developed economies that have witnessed a surge in large-scale corporate bribery scandals in recent years.

\section{ACKNOWLEDGEMENTS}

We thank the editor, the anonymous reviewers, Robert Akerlof, Kaushik Basu, Michael Ginzberg, Susan Rose-Ackerman, James H. Stock, Aks Zaheer, and the participants at the American Law and Economics Association annual meeting, World Bank's Annual Bank Conference on Development Economics, the Northeast Universities Development Consortium (NEUDC) Conference, INSEAD Conference on Network Evolution, Georgetown University-Responsible Organizations in the Global Context Conference, CUHK Conference on Institutions and Governance, the Academy of International Business annual meeting, the Academy of Management annual meeting, as well as seminar audiences at Harvard Business School (HBS), MIT, University of Minnesota, Rutgers University, Hong Kong Baptist University and American University (AU) for helpful comments. We also thank a number of field specialists at Global Witness, Omidyar Network, and Transparency International UK Chapter in London, the Korea Society and the Rockefeller Foundation in New York, and the Transparency and Accountability Initiative, the World Bank's Governance Global Practice, the Global Financial Integrity in Washington, D.C. for their feedback. This project was supported by the Academy of Korean Studies Grant (AKS-2015-R33), the Office of Research Integrity of AU, the HBS 
Division of Research and the Asia Library at the University of Michigan with support from the U.S. Department of Education Title VI grant. All remaining errors are our own.

\section{REFERENCES}

Ades, A., \& Di Tella, R. (1999). Rents, competition, and corruption. American Economic Review, 89(4), 982-993.

Allison, P. D., \& Waterman, R. P. (2002). Fixed-effects negative binomial regression models. Sociological Methodology, 32, 247-265.

Almenberg, J., \& Dreber, A. (2009). Lady and the Trump: Status and wealth in the marriage market. Kyklos, 62(2), 161-181.

Amsden, A. H. (1989). Asia's next giant: South Korea and Late Industrialization. Oxford, England: Oxford University Press.

Amsden, A. H. (2001). The rise of "the rest": challenges to the West from late-industrializing economies. Oxford, England: Oxford University Press.

Askin, N., \& Bothner, M. S. (2016). Status-aspirational pricing: The "Chivas Regal” strategy in U.S. higher education, $2006-2012$. Administrative Science Quarterly, 61(2), 217-253.

Balasubramanian, P., Bennett, V. M., \& Pierce, L. (2017). The wages of dishonesty: The supply of cheating under high-powered incentives. Journal of Economic Behavior \& Organization, 137, 428-444.

Ball, S., Eckel, C., Grossman, P. J., \& Zame, W. (2001). Status in markets. Quarterly Journal of Economics, 116(1), 161-188.

Barker, H. (2017). Family and business during the industrial revolution. Oxford, England: Oxford University Press.

Baron, D. P. (2013). Business and its environment (7th ed.). Upper Saddle River, NJ: Prentice-Hall.

Becker, H. (1963). Outsiders, studies in the sociology of deviance. New York, NY: Free Press.

Bonacich, P. (1987). Power and centrality: A family of measures. American Journal of Sociology, 92(5), 1170-1183.

Borgatti, S. P., Everett, M. G., \& Freeman, L. C. (2002). Ucinet 6 for windows: Software for social network analysis. Analytic Technologies: Harvard, MA.

Bunkanwanicha, P., Fan, P. H. J., \& Wiwattanakantang, Y. (2013). The value of marriage to family firms. Journal of Financial and Quantitative Analysis, 48(2), 611-636.

Cameron, A. C., \& Trivedi, P. K. (2015. Chapter 8). Count panel data. In B. H. Baltagi (Ed.), Oxford handbook of panel data econometrics (pp. 233-256). Oxford, England: Oxford University Press.

Chavis, L. (2013). Social networks and bribery: The case of entrepreneurs in Eastern Europe. Journal of Comparative Economics, 41(1), 279-293.

Cheung, Y. L., Rau, R. P., \& Stouraitis, A. (2012). How much do firms pay as bribes and what benefits do they get? Evidence from corruption cases worldwide (NBER Working paper 17981). National Bureau of Economic Research, Cambridge, MA. Retrieved from http://www.nber.org/papers/w17981.

Cho, D. S. (1997). Mae Kyung Daily Newspaper. Korean Chaebols. Seoul. (title translated from Korean).

Clarke, G. R. G., \& Xu, L. C. (2004). Privatization, competition, and corruption: How characteristics of bribe takers and payers affect bribes to utilities. Journal of Public Economics, 88(9-10), 2067-2097.

Cyert, R., \& March, J. (1963). A behavioral theory of the firm. Englewood Cliffs, NJ: Prentice-Hall.

Dittes, J. E., \& Kelley, H. H. (1956). Effects of different conditions of acceptance upon conformity to group norms. Journal of Abnormal and Social Psychology, 53(1), 100-107.

Fisman, R. (2001). Estimating the value of political connections. American Economic Review, 91(4), 1095-1102.

Fisman, R., \& Miguel, E. (2007). Corruption, norms, and legal enforcement: Evidence from diplomatic parking tickets. Journal of Political Economy, 115(6), 1020-1048.

Fisman, R., \& Wei, S. J. (2009). The smuggling of art, and the art of smuggling: Uncovering the illicit trade in cultural property and antisques. American Economic Journal: Applied Economics, 1(3), 82-96.

Giordano, P. C. (1983). Sanctioning the high-status deviant: An attributional analysis. Social Psychology Quarterly, 46(4), $329-342$.

Gourieroux, C., Monfort, A., \& Trognon, A. (1984). Pseudo maximum likelihood methods: Applications to Poisson models. Econometrica, 52(3), 701-720.

Grassby, R. (2001). Kinship and capitalism: Marriage, family, and business in the english-speaking world, 1580-1740. Cambridge, England: Cambridge University Press.

Greene, W. (2007). Fixed and random effects models for count data. (NYU Working paper EC-07-16). New York University, New York, NY. Retrieved from https://ssrn.com/abstract=1281928.

Greene, W. (2010). Testing hypotheses about interaction terms in nonlinear models. Economics Letters, 107(2), $291-296$.

Greve, H. R. (2003). Organizational learning from performance feedback: A behavioral perspective on innovation and change. Cambridge, England: Cambridge University Press.

Greve, H. R., Han, J. Y., \& Shipilov, A. (2016). Unequal bedfellows: Gender role-based differences in multiplex ties between Korean business groups. Academy of Management Journal, 60(4), 1531-1553.

Grolleau, G., Kocher, M. G., \& Sutan, A. (2016). Cheating and loss aversion: Do people cheat more to avoid a loss? Management Science, 62(12), 3428-3438.

Hansen, C. B. (2007). Asymptotic properties of a robust variance matrix estimator for panel data when T is large. Journal of Econometrics, 141(2), 597-620. 
Huntington, S. P. (1991). The third wave: Democratization in the late Twentieth Century. Norman, OK: University of Oklahoma Press.

Ingram, P., \& Lifschitz, A. (2006). Kinship in the shadow of the corporation: The interbuilder network in Clyde River shipbuilding, 1711-1990. American Sociological Review, 71(2), 334-352.

Jeong, Y., Siegel, J. I., \& Chen, S. Y. (2017). A recentering approach for interpreting interaction effects from logit, probit, and other nonlinear models (Working paper).

Jeong, Y., \& Weiner, R. J. (2012). Who bribes? Evidence from the United Nations' oil-for-food program. Strategic Management Journal, 33(12), 1363-1383.

Kahneman, D. (2013). Thinking, fast and slow. New York, NY: Farrar, Straus and Giroux.

Kahneman, D., \& Tversky, A. (1979). Prospect theory: An analysis of decision under risk. Econometrica, 47(2), $263-291$.

Kang, D. C. (2002). Crony capitalism corruption and development in South Korea and the Philippines. Cambridge, England: Cambridge University Press.

Kaufmann, D. (2006). Chapter 2.1. Myths and realities of governance and corruption. In World Economic Forum (Ed.), (ed) The Global Competitive Report 2005-2006 (pp. 81-98). Basingstoke: Palgrave Mcmillan. Retrieved from http://web.worldbank.org/ archive/website00818/WEB/GCR2005.HTM

Kern, M. C., \& Chugh, D. (2009). Bounded ethicality the perils of loss framing. Psychological Science, 20(3), 378-384.

Kim, E. M. (1997). Big business, strong state collusion and conflict in South Korean development, 1960-1990. Albany, NY: State University of New York Press.

Kogut, B. (2012). The small world of corporate governance: An introduction. In B. Kogut (Ed.), The small worlds of corporate governance (pp. 1-52). Cambridge, MA: MIT Press.

Lancaster, T. (2000). The incidental parameters problem since 1948. Journal of Econometrics, 95(2), 391-414.

La Porta, R., Lopez-de-Silanes, F., Shleifer, A., \& Vishny, R. (1997). Legal determinants of external finance. Journal of Finance, 52(3), 1131-1150.

La Porta, R., Lopez-de-Silanes, F., Shleifer, A., \& Vishny, R. (2000). Investor protection and corporate governance. Journal of Financial Economics, 58(1-2), 3-27.

La Porta, R., Lopez-de-Silanes, F., Shleifer, A., \& Vishny, R. (2002). Investor protection and corporate valuation. Journal of Finance, $57(3), 1147-1170$.

Malter, D. (2014). On the causality and cause of returns to organizational status: Evidence from the grands crus classés of the Médoc. Administrative Science Quarterly, 59(2), 271-300.

McMillan, J., \& Zoido, P. (2004). How to subvert democracy: Montesinos in Peru. The Journal of Economic Perspectives, 18(4), 69-92.

Martin, K. D., Cullen, J. B., Johnson, J. L., \& Parboteeah, K. P. (2007). Deciding to bribe: A cross-level analysis of firm and host country influences on bribery activity. Academy of Management Journal, 50(6), 1401-1422.

Merton, R. K. (1968). Social theory and social structure. New York, NY: Free Press.

Mishina, Y., Dykes, B. J., Block, E. S., \& Pollock, T. G. (2010). Why 'good' firms do bad things: The effects of high aspirations, high expectations, and prominence on the incidence of corporate illegality. Academy of Management Journal, 53(4), 701-722.

Møller, J., \& Skaaning, S. (2013). The third wave: Inside the numbers. Journal of Democracy, 24(4), 97-109.

Olken, B. A., \& Barron, P. (2009). The simple economics of extortion: Evidence from trucking in Aceh. Journal of Political Economy, 117(3), 417-452.

Padgett, J. F., \& Ansell, C. K. (1993). Robust action and the rise of the Medici, 1400-1434. American Journal of Sociology, 98(6), $1259-1319$.

Padgett, J. F., \& McLean, P. D. (2006). Organizational invention and elite transformation: The birth of partnership systems in Renaissance Florence. American Journal of Sociology, 111(5), 1463-1568.

Park, J. R. (1988, October). The Ilhae foundation. Sin-dong-a, Dong-a Daily Newspaper.

Phillips, D. J., \& Zuckerman, E. W. (2001). Middle-status conformity: Theoretical restatement and empirical demonstration in two markets. American Journal of Sociology, 107(2), 379-429.

Podolny, J. M. (2005). Status signals: A sociological study of market competition. Princeton, NJ: Princeton University Press.

Rhee, J. C. (2002). The state and industry in South Korea: The limits of the authoritarian state. New York, NY: Routledge.

Rider, C. I., \& Tan, D. (2015). Labor market advantages of organization status: A study of lateral partner hiring by large U.S. law firms. Organization Science, 26(2), 356-372.

Rose-Ackerman, S. (1975). The economics of corruption. Journal of Public Economics, 4(2), 187-203.

Rose-Ackerman, S. (1978). Corruption: A study in political economy. New York, NY: Academic Press.

Rose-Ackerman, S. (1999). Corruption and government: causes, consequences, and reform. Cambridge, England: Cambridge University Press.

Santos Silva, J. M. C., \& Tenreyro, S. (2006). The log of gravity. Review of Economics and Statistics, 88(4), 641-658.

Sauder, M., Lynn, F., \& Podolny, J. M. (2012). Status: Insights from organizational sociology. Annual Review of Sociology, 38(1), $267-283$.

Seo, J. S. (2007). Contemporary history of South Korea - 60 years. Translated by Sohn Jung In. Seoul, South Korea: Korea Democracy Foundation. 
Sequeira, S., \& Djankov, S. (2014). Corruption and firm behavior: Evidence from African ports. Journal of International Economics, 94(2), 277-294.

Shleifer, A., \& Vishny, R. W. (1993). Corruption. The Quarterly Journal of Economics, 108(3), 599-617.

Shleifer, A., \& Vishny, R. W. (2002). The grabbing hand: Government pathologies and their cures. Cambridge, MA: Harvard University Press.

Siegel, J. I. (2007). Contingent political capital and international alliances: Evidence from South Korea. Administrative Science Quarterly, 52(4), 621-666.

Siegel, J. I., \& Larson, B. Z. (2009). Labor market institutions and global strategic adaptation: Evidence from Lincoln Electric. Management Science, 55(9), 1527-1546.

Smith, A. (1976). In D. D. Raphael \& A. L. Macfie (Eds.), The theory of moral sentiments. Oxford, England: Clarendon Press.

Stock, J. H., \& Watson, M. W. (2008). Heteroskedasticity-robust standard errors for fixed effects panel data regression. Econometrica, $76(1), 155-174$.

Suh, S. (1996). Time of Reckoning. Retrieved from http://edition.cnn.com/ASIANOW/asiaweek/96/1227/cs3.html.

Svensson, J. (2003). Who must pay bribes and how much? Evidence from a cross section of firms. Quarterly Journal of Economics, $118(1), 207-230$.

The National Assembly of the Republic of Korea. (1990). Investigative Report on High-level Corruption Scandals during the Fifth Republic by the Special Committee of the National Assembly (NADB1199222190), July.

Vaughan, D. (1999). The challenger launch decision: Risky technology, culture, and deviance at NASA. Chicago, IL: University of Chicago Press.

Van Vu, H., Tran, T. Q., Van Nguyen, T., \& Lim, S. (2016). Corruption, types of corruption and firm financial performance: New evidence from a transitional economy. Journal of Business Ethics, 2(1), 1-12.

Washington, M., \& Zajac, E. J. (2005). Status evolution and competition: Theory and evidence. The Academy of Management Journal, 48(2), 282-296.

Weisburd, D., Wheeler, S., Waring, E., \& Bode, N. (1991). Crimes of the middle classes: White-collar offenders in the federal courts. New Haven, CT: Yale University Press.

Wheeler, S. (1992). The Problem of white-collar crime motivation. In K. Schlegel \& D. Weisburd (Eds.), White-collar crime reconsidered (pp. 108-123). Boston, MA: Northeastern University Press.

Wooldridge, J. M. (1997). Quasi-likelihood methods for count data. In M. Pesaran \& P. Schmidt (Eds.), Handbook of applied econometrics, volume ii: Microeconometrics (pp. 352-406). Malden, MA: Blackwell.

Wooldridge, J. M. (2010). Econometric analysis of cross section and panel data (2nd ed.). Cambridge, MA: MIT Press.

World Bank. (2017). World development indicators. Washington, D.C. Retrieved from www.worldbank.org

Yoo, Y. (1988, June). Cozy government-business relationship during Chun's regime. Sin-dong-a, Dong-a Daily Newspaper, (title translated from Korean).

\section{SUPPORTING INFORMATION}

Additional Supporting Information may be found online in the supporting information tab for this article.

How to cite this article: Jeong Y, I. Siegel J. Threat of falling high status and corporate bribery: Evidence from the revealed accounting records of two South Korean presidents. Strat Mgmt J. 2018;39:1083-1111. https://doi.org/10.1002/smj.2747 